\title{
Six new species of Anthuridae (Peracarida: Isopoda) from the southern Mexican Pacific
}

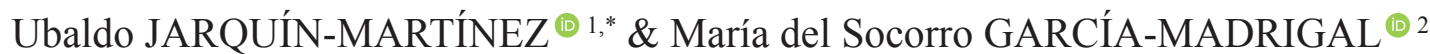 \\ ${ }_{1,2}$ Universidad del Mar, campus Puerto Ángel, Laboratorio de Sistemática de Invertebrados Marinos \\ (LABSIM), Ciudad Universitaria, Puerto Ángel, Oaxaca, 70902, México. \\ "Corresponding author: ubaldo096@hotmail.com \\ 2Email:ms_garcia_m@hotmail.com \\ ${ }^{1}$ urn:1sid:zoobank.org:author:4CBA11BB-583F-4AD7-B604-D7FC3FA2C90E \\ ${ }^{2}$ urn:1sid:zoobank.org:author:07C47E60-3BB1-4260-9CBA-03E0CEC0F2B3
}

\begin{abstract}
Marine isopods, despite being a very diverse group, have been little studied in the Mexican South Pacific. After a revision of 171 specimens collected from Guerrero and Oaxaca, six new species, belonging to five genera, were discovered: Amakusanthura guerrerensis sp. nov., Cortezura caeca sp. nov., Mesanthura antenniformis sp. nov., M. estacahuitensis sp. nov., Skuphonura oaxaquensis sp. nov., and Tinggianthura mexicana sp. nov. In this work, the genera Amakusanthura Nunomura, 1977 and Tinggianthura Chew, Abdul-Rahim \& Haji Ross, 2014, are recorded for the first time in the Tropical Eastern Pacific. Also, the distribution range of the genus Skuphonura Barnard, 1925 is increased from the west coast of South America to the southern Mexican Pacific, this being the first record of this genus in the Mexican Pacific. This study doubles the number of species recorded of Anthuridae from the Mexican Pacific, of six to 12 species.
\end{abstract}

Keywords. Amakusanthura, Cortezura, Mesanthura, Skuphonura, Tinggianthura.

Jarquín-Martínez U. \& García-Madrigal M.S. 2021. Six new species of Anthuridae (Peracarida: Isopoda) from the southern Mexican Pacific. European Journal of Taxonomy 760: 61-100. https://doi.org/10.5852/ejt.2021.760.1441

\section{Introduction}

Marine isopods, despite being a very diverse group, with more than 6250 species described in the World (Poore \& Bruce 2012), have been little studied in the Mexican South Pacific. Only 28 species have been recorded in this region, of these only one species of Anthuridae Leach, 1814 has been recorded, Cortezura penascoensis Schultz, 1977 (Espinosa-Pérez \& Hendrickx 2001; Bastida-Zavala et al. 2013).

The Anthuridae is the largest family within the anthuridean isopods (Chew et al. 2014). It currently comprises 26 genera and 302 species (Boyko et al. 2008 onwards). Approximately $65 \%$ of these species are distributed in tropical waters and $30 \%$ in warm temperate waters; however, also are frequent in cold and polar regions. Some are found in brackish and freshwater environments but mostly live seashore in sediments of different substrates such as coral reefs, algae, coral rubble, and associated with other invertebrates (Poore 2001; Poore \& Bruce 2012). 
The most significant characteristics that distinguish Anthuridae from other anthuridean isopods are (1) antenna flagellum with less than 10 articles, shorter than peduncles; (2) mouthparts not produced anteriorly; (3) maxilliped palp twice as long as wide, with 2-4 articles; (4) pereopods 2-6 propodus palm with 1 distal robust seta only, pereopod 7 propodus with three distal robust setae; (5) telson with one pair of statocysts (Poore 2001).

The Anthuridae family have been poorly studied in the Mexican Pacific, and the few studies available are focused on the northern region of the Pacific of Mexico. Among them stand out the descriptions of two species from Gulf of California, Cortezura penascoensis and Mesanthura nubifera Wägele, 1984. Additionally, in the Western coast of Baja California, Menzies (1962) and Campos \& Villarreal (2008) recorded to Haliophasma geminata Menzies \& Barnard, 1959 and Mesanthura occidentalis Menzies \& Barnard, 1959; in the Gulf of California, Brusca (1980) only recorded to Mesanthura sp. and EspinosaPérez \& Hendrickx (2001) recorded to M. occidentalis, both in the Gulf of California and in the central Pacific of Mexico.

In this study, we describe six new species of Anthuridae from southern Mexican Pacific, belonging to five genera.

\section{Material and methods}

The revised specimens are from the Crustacea section of the Scientific Collection (OAX-CC-249-11) of the Laboratorio de Sistemática de Invertebrados Marinos (LABSIM), Universidad del Mar, Puerto Ángel, Oaxaca. The specimens are derived from 13 localities along the coast of Guerrero and Oaxaca (Fig. 1). All material was collected from intertidal and subtidal zone (1-12 $\mathrm{m}$ depth) by free diving and scuba on different substrates such as rock, coral, coralline rocks, sand, algae and shells. Collected specimens were fixed $4 \%$ formalin and preserved in $70 \%$ ethanol.

The specimens were examined with a stereo microscope and separated by morphotypes. The best preserved specimens of each species were measured from the rostrum to the end of telson and the habitus was drawn with a camera lucida. Left appendages were dissected and mounted on glycerol and sealed with Entellan ${ }^{\odot}$ on permanent slides. Drawings of each structure dissected were made using a digital camera and a WACOM brand graphic drawing tablet using Adobe Photoshop CS6 program.

The identification was made using the specialized literature and identification keys of Poore (2001) and Chew et al. (2014). Diagnoses and descriptions of the species were standardized and the nomenclature of the structures was based on the terminology of Negoescu (1994) and Garm \& Watling (2013). All material examined was labeled, catalogued and deposited in the Crustacea section, Scientific Collection of Laboratorio de Sistemática de Invertebrados Marinos (LABSIM), Universidad del Mar.
Abbreviations
$\mathrm{A} 1=$ Antennule
$\mathrm{A} 2=$ Antenna
$\mathrm{C}=$ Cephalon
$\mathrm{P}=$ Pereopod
$\mathrm{Pl}=$ Pleopod 

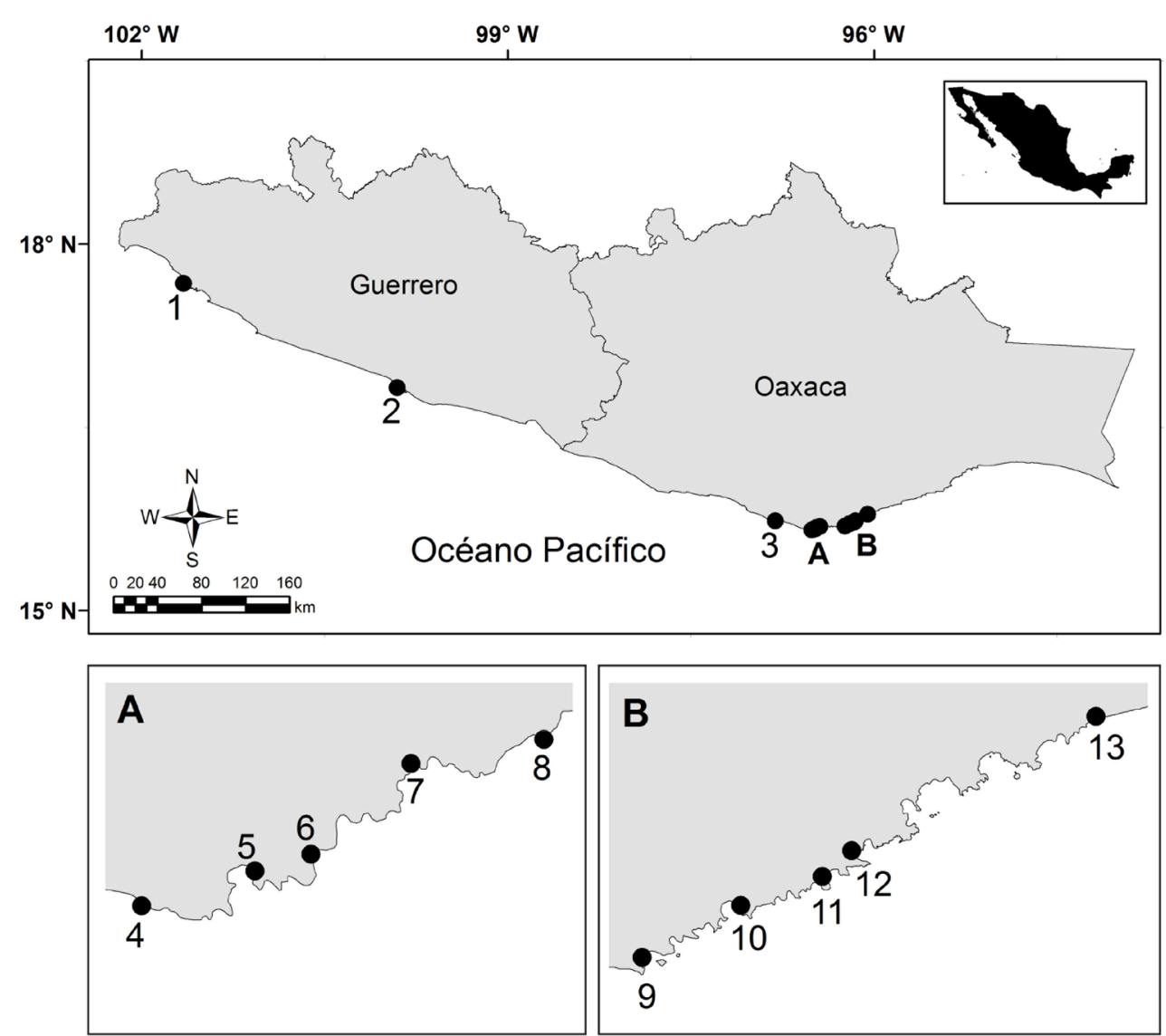

Fig. 1. Study area. Guerrero: 1. Coral Beach. 2. La Roqueta Island. A-B. Oaxaca: 3. Agua Blanca Beach. 4. Zipolite, Playa del Amor. 5. Puerto Ángel Bay. 6. Estacahuite Beach. 7. La Boquilla Beach. 8. La Tijera Beach. 9. San Agustín Bay. 10. Chachacual Bay, Jicaral Beach. 11. Cacaluta Bay. 12. El Maguey Bay. 13. Copalita Beach.

\section{Results}

\section{Systematics}

Class Malacostraca Latreille, 1802

Superorder Peracarida Calman, 1904

Order Isopoda Latreille, 1817

Suborder Cymothoida Wägele, 1989

Superfamily Anthuroidea Leach, 1914

Family Anthuridae Leach, 1814

Genus Amakusanthura Nunomura, 1977

Amakusanthura guerrerensis sp. nov. urn:Isid:zoobank.org:act:B887EED9-16EB-433E-9F69-ACD26CA84B62

Figs 2-4, 20A

\section{Etymology}

This species is named after Guerrero, the Mexico State where the type material was collected. 


\section{Material examined}

Holotype

MEXICO - $q$ (body length $5 \mathrm{~mm}$ ); Guerrero, Ixtapa Island, Coral Beach, E-1A; $17^{\circ} 40^{\prime} 38^{\prime \prime} \mathrm{N}$, $101^{\circ} 39^{\prime} 20^{\prime \prime}$ W; depth 1.5 m; 19 Sep. 2007; M.S García-Madrigal et al. leg.; coral rock; UMARPERA 522.

\section{Paratypes}

MEXICO $\bullet 2$ $q q$ (ovigerous), 4 $q+, 2$ mancae; same collection data as for holotype; UMAR-PERA 523.

\section{Additional material}

MEXICO - Guerrero • 4 q $q, 5$ mancae; Ixtapa Island, Coral Beach, E-1B; 1740'38" N, 101 $39^{\prime} 20^{\prime \prime}$ W; depth intertidal; 19 Sep. 2007; M.S García-Madrigal et al. leg.; algae; UMAR-PERA 524 • 7 우,

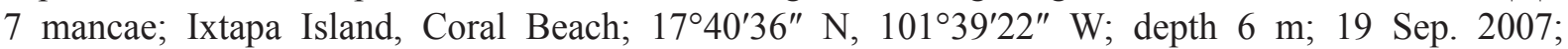
M.S. García-Madrigal et al. leg.; coral; UMAR-PERA 525 • 4 + 9 , 1 manca; Acapulco, La Roqueta Island; 1649'26" N, 99 54'29" W; depth 2 m; 21 Sep. 2007; M.S. García-Madrigal et al. leg.; tubes

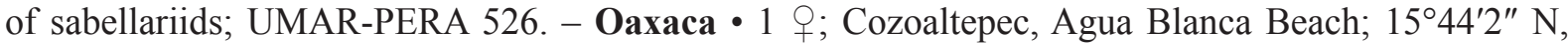
96 48'32" W; depth intertidal; 11 Nov. 2007; I. López-Aguilar et al. leg.; algae; UMAR-PERA 527 - 3 우, 1 manca; Puerto Ángel, Estacahuite Beach; $15^{\circ} 40^{\prime} \mathrm{N}, 96^{\circ} 29^{\prime} \mathrm{W}$; depth $0.5 \mathrm{~m}$; 3 Jul. 2007; J. Jarquín-González et al. leg.; coral; UMAR-PERA 528 • 2 우 (ovigerous), 6 웅, 1 đ 0 , 2 mancae;

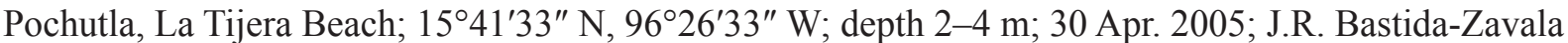
et al. leg.; coral rock; UMAR-PERA 529 • 1 o, 1 manca; Pochutla, La Tijera Beach; 1541'33" N, 96 26'33" W; depth 3 m; 7 Apr. 2009; F. Cortés-Carrasco et al. leg.; coral rock; UMAR-PERA 530

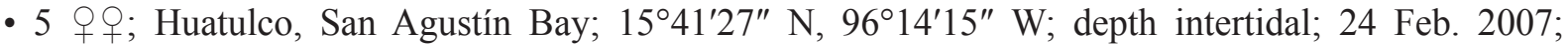
M.S. García-Madrigal et al. leg.; coral algae; UMAR-PERA 531 • 3 o $O$; Huatulco, San Agustín Bay; $15^{\circ} 41^{\prime} 22^{\prime \prime}$ N, 96 $6^{\circ} 14^{\prime} 14^{\prime \prime}$ W; depth intertidal; 24 Oct. 2013; H. Solano-García leg.; coral rock; UMAR-

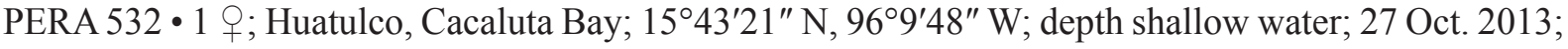
R. Rodríguez leg.; Spondylus shells; UMAR-PERA 533.

\section{Description}

Holotype ( $q$, UMAR-PERA 522)

Body (Figs 2A, 4E, 20A). Length $5 \mathrm{~mm}$, about 10 times as long as wide with a brown pigment band at the posterior margin of the pereonites 3-7 and pleonite 5; moderately setose caudal region; body proportion: $\mathrm{C}<1=2=3<4>5<6>7$. Subcircular cephalon as wide as long; rostral process subequal to the lateral angles. Eyes small, black. Pleonites 1-5 about 1.1 times as long as pereonite 7; pleonites 1-3 with dorsal folds; pleonites 4-5 dorsally fused; pleonite 6 with a median incision at the distal margin. Telson linguiform, medially wider, narrowing distally, rounded apex with numerous marginal setae, proximal region with a pair of statocysts.

Antennule (Fig. 2B). Peduncle with three articles. Articles 1 and 2 with plumose sensory setae; article 2 quadrate, 0.7 times as long as third article, external margin with three long simple setae; flagellum with three articles, subequal to the length of the third peduncular article; tiny distal article with one aesthetasc and a group of simple setae.

Antenna (Fig. 2C). Peduncle with five articles. Article 2 rudimentary, subequal in length to articles 2 and 3 together, internal lateral margin with scales; article 4 quadrate, with a group of simple setae at the distal angles; article 5 rectangular, 1.3 times as long as the fourth. Flagellum rudimentary with four articles, 0.6 times as long as last peduncular article. 
MaXiLliped (Fig. 2D). Palp with three articles. Article 1 rectangular with one simple seta; article 2 with one long medial seta and three distal setae, internal margin with setulated scales, bilobed and projected distal angle; article 3 small, oblique with five distal setae. Endite reaching half of the first article of palp.

Maxilla (Fig. 2E). Straight with seven stout distal teeth.

MandiBle (Fig. 2F). Symmetrical; palp with three articles, first article 0.6 times as long as article 2 with a long distal seta; second article 2.5 times as long as article 3 with three distal setae; article 3 with five pectinate setae. Incisor with three teeth; lacinia mobilis with four denticles.

Pereopod 1 (Fig. 3A). Subchelate; carpus triangular, apex truncated and crenulated; propodus ovate, 1.8 times as long as wide, palm with middle projection as a step with eight robust short setae; internal distal angle of dactylus projected.

Pereopods 2-3 (Fig. 3B-C). Similar in shape and size. Carpus triangular, truncated apically with a small tooth and two long robust setae; propodus elongated oval, 2.1-2.2 times as long as wide, internal margin with a row of simple setae and setulated scales, distoventrally one slightly serrated sensory spine; proximal internal margin of the dactylus with small teeth, distal margin with a robust spine and a group of simple and plumose setae.

Pereopods 4-7 (Fig. 3D-G). Very similar in shape and size. Merus with a row of long simple setae and setules on inner margin; carpus subpentagonal, ventrodistal margin with a sensory spine and simple setae, dorsodistal margin with a plumose sensory seta; propodus sub-cylindrical, 1.8 times as long as wide in P4-6, and 2.5 times in P7; ventral margin with simple seta and setulated scales, ventrodistal margin with a denticulate sensory spine. P7 ventrodistally with two pectinate sensory spines; dactylus with setulated scales.

Pleopod 1 (Fig. 4A). Protopod with five retinaculae; exopod operculiform, 2.3 times as wide as the endopod, external margin with a medial seta, internal margin with a proximal seta; surrounded laterally and apically by 48 plumose setae; endopod cylindrical, shorter than exopod with six plumose setae on distal margin.

Pleopod 2 (Fig. 4B). Oval and elongated, exopod surrounded distally by 14 plumose setae; endopod shorter than exopod, surrounded by eight plumose setae.

UROPODAL PROTOPOD (Fig. 4C). Rectangular, 1.2 times as long as endopod, inner margin with seven plumose setae, outer margin with a row of plumose setae.

UROPODAL ENDOPOD (Fig. 4C). Apex rounded, 1.7 times as long as wide, distally and laterodistally surrounded by long simple setae.

Uropodal EXopod (Fig. 4D). Oval, distally emarginated, 1.6 times as long as wide, surrounded by 67 setae, 21 smooth and 46 plumose.

\section{Distribution and habitat}

From Ixtapa, Guerrero to Huatulco, Oaxaca. In algae, coral, coral rock, tubes of sabellariids and molluscan shells; intertidal to subtidal (6 m).

\section{Remarks}

Amakusanthura guerrerensis sp. nov. shares the following characteristics with 41 previously recorded species of the genus: (1) maxillipedal palp with three free articles, the internal angle of the second article 

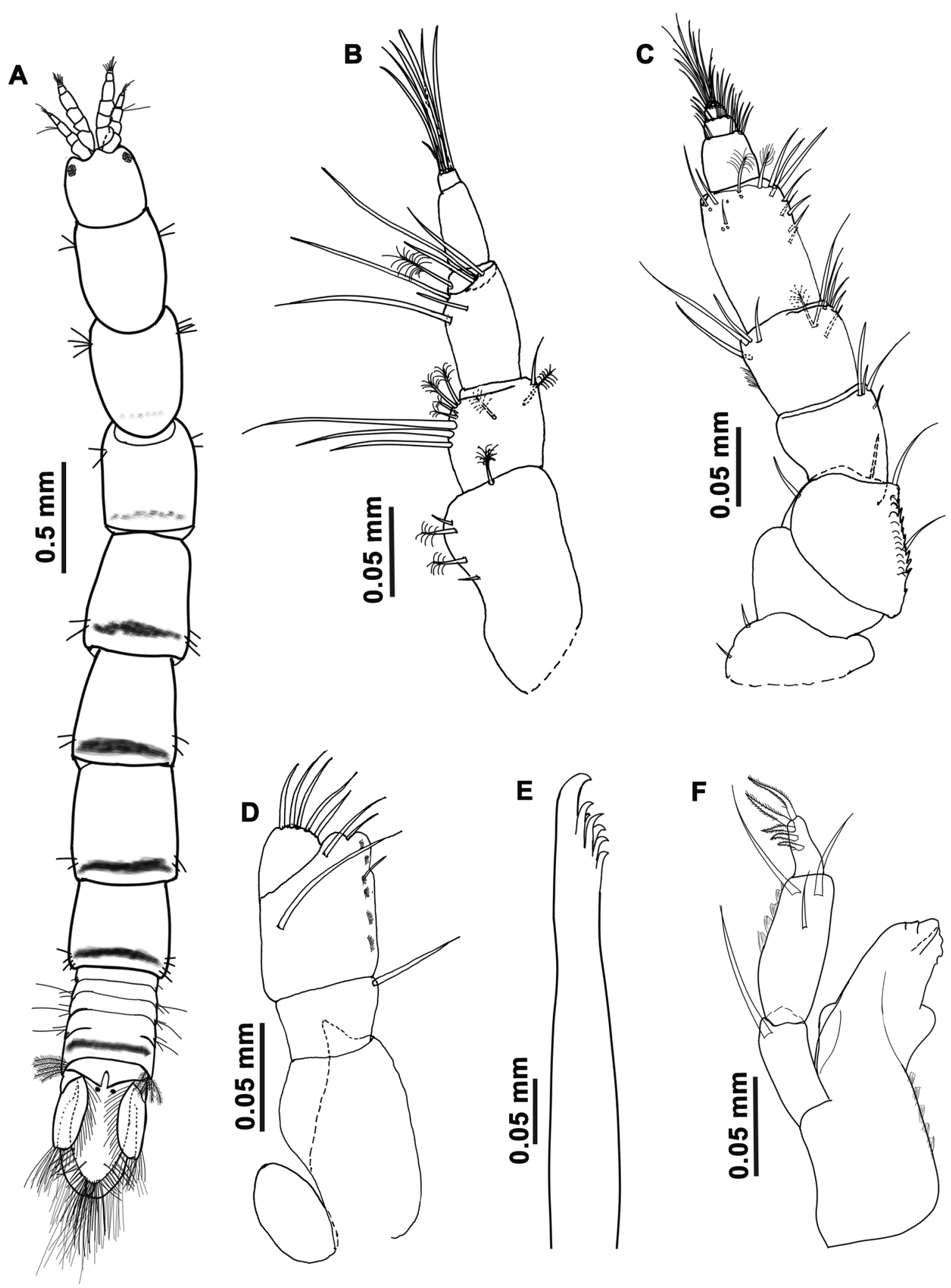

Fig. 2. Amakusanthura guerrerensis sp. nov., holotype, $\circ, 5 \mathrm{~mm}$, Guerrero, Ixtapa Island, Coral Beach (UMAR-PERA 522). A. Habitus. B. Antennule. C. Antenna. D. Maxilliped. E. Maxilla. F. Mandible (right). 

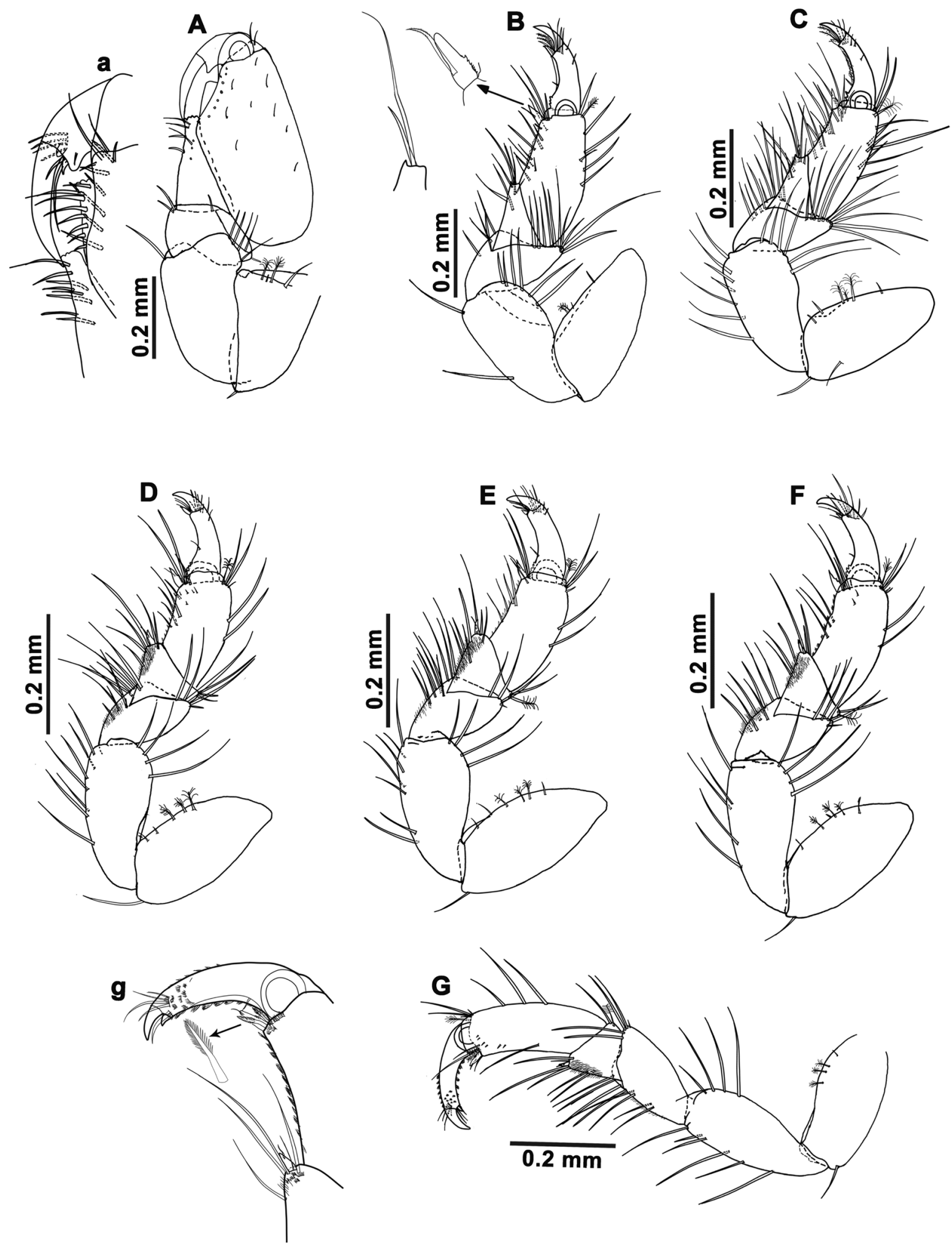

Fig. 3. Amakusanthura guerrerensis sp. nov., holotype,, , $5 \mathrm{~mm}$, Guerrero, Ixtapa Island, Coral Beach (UMAR-PERA 522). A. Pereopod 1 and detail of the palm (a). B. Pereopod 2 and detail of the carpus and sensory spine. C. Pereopod 3. D. Pereopod 4. E. Pereopod 5. F. Pereopod 6. G. Pereopod 7 and detail of the propodus and dactylus $(\mathrm{g})$. 
projected; (2) pleon longer than wide; (3) pleonites 1-3 with dorsal suture lines and 4-5 dorsally fused. The new species differs by presenting a unique combination of characteristics: antenna with scales in the internal margin of the second article; palm of the pereopod 1 with a medial projection as a step armed with eight short setae; exopod of pleopod 1 with one proximal and medial simple seta, and 48 distal plumose setae. Amakusanthura guerrerensis sp. nov. is similar to A. californiensis (Schultz, 1964), the only species recorded in the eastern Pacific, with the following characteristic: (1) more than eight setae in the distolateral part of the telson. The new species, however, differs from A. californiensis in the presence of a pigmented line in the pereonites 3-7 and pleonite 5, distal article of the mandibular palp
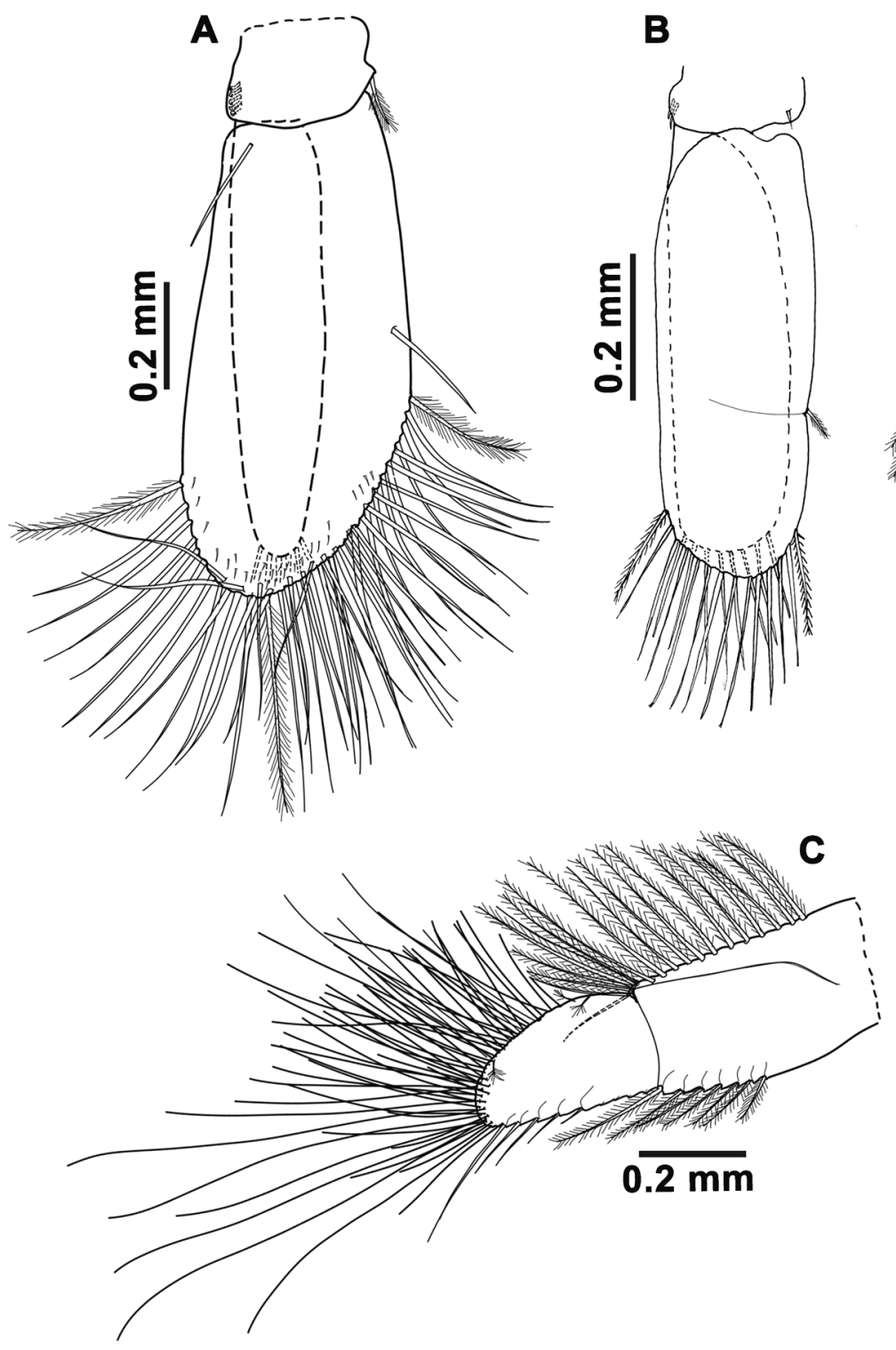
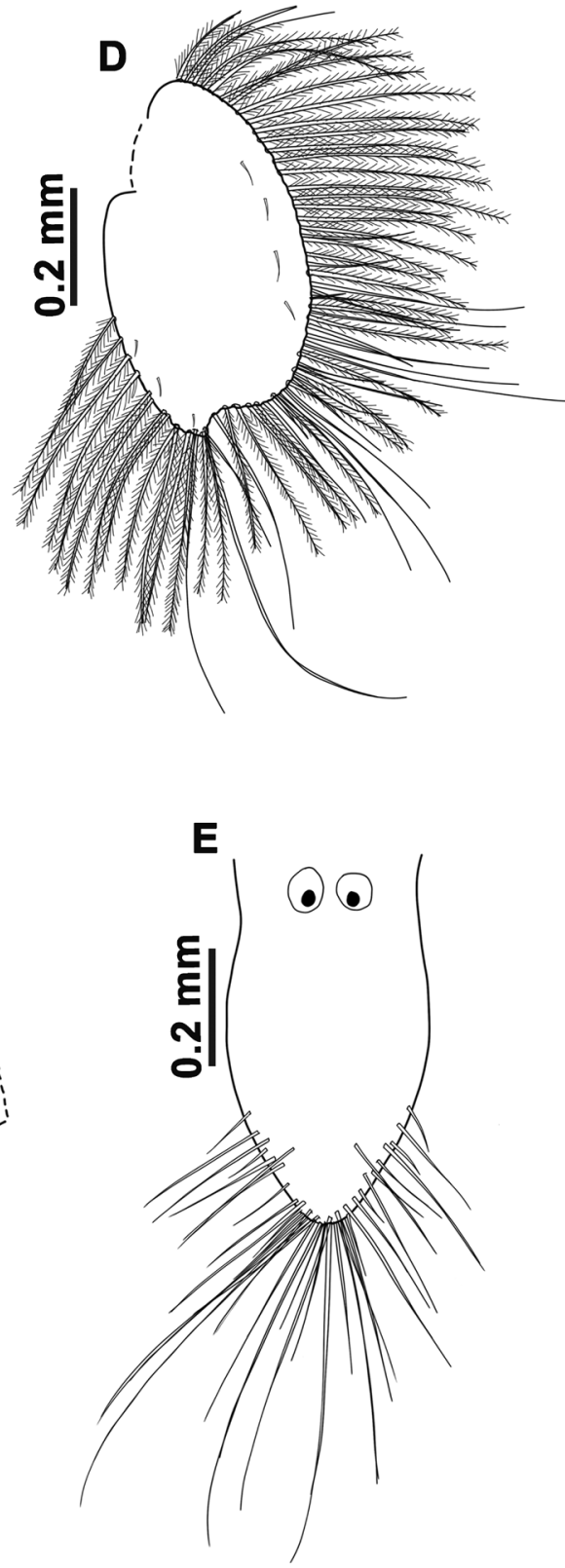

Fig. 4. Amakusanthura guerrerensis sp. nov., holotype,,$+ 5 \mathrm{~mm}$, Guerrero, Ixtapa Island, Coral Beach (UMAR-PERA 522). A. Pleopod 1. B. Pleopod 2. C. Uropodal endopod. D. Uropodal exopod. E. Telson. 
with five pectinate setae, palm of the pereopod 1 with a medial projection as a step armed with eight short setae and pleonite 6 is strongly emarginated. In comparison, A. californiensis has no pigment, the distal article of the mandibular palp has four setae, palm straight, and the pleonite 6 is slightly emarginated.

\section{Genus Cortezura Schultz, 1977}

Cortezura caeca sp. nov. urn:lsid:zoobank.org:act:AE0F227A-7FA9-4897-B29F-7C32EBF9214A

Figs 5-7, 20B

\section{Etymology}

This species is named after 'caeca' due to the absence of eyes.

\section{Material examined}

\section{Holotype}

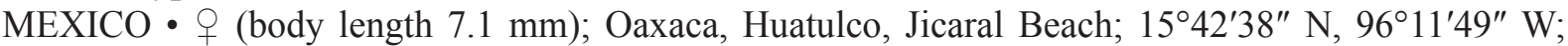
depth 12 m; 11 Feb. 2007; V. Hernández-Urraca and L. Estrada-Vargas leg.; coral; UMAR-PERA 534.

\section{Paratypes}

MEXICO • 1 ( (body length $8 \mathrm{~mm}$ ); same collection data as for holotype; UMAR-PERA 535 • 1 क; same collection data as for holotype; UMAR-PERA 536.

\section{Additional material}

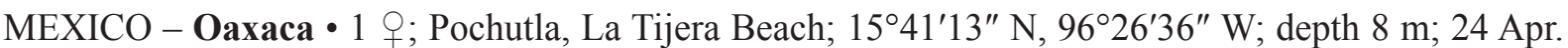
2009; D. Zavala-Casas leg.; sand; UMAR-PERA $537 \cdot 3$ 우, 1 §; Huatulco, Copalita Beach, in front of the mouth of the Copalita River; 15 47'17" N, 96 $3^{\circ} 5^{\prime \prime}$ W; depth 10 m; 7 May 2007; E. MoralesDomínguez and C. Hernández-Tlapale leg.; sediment; UMAR-PERA 538.

\section{Description}

\section{Holotype ( 9 , UMAR-PERA 534)}

Body (Figs 5A, 20B). Length $7.1 \mathrm{~mm}$, about 11.8 times as long as wide with a whitish color, without pigment. Body proportion: $\mathrm{C}<1=2>3<4<5>6>7$. Cephalon 1.3 times as long as wide, rostral process equal to lateral lobes, eyes absent; overlapping antennas, forming a flattened surface. Pleon equals to the length of the pereonite 7; pleonites 1-5 fused, pleonite 6 free. Telson 2.6 times as long as wide, tapering distally with two proximal statocysts, mid-distal margin with a group of short setae; apex broadly truncate, slightly sinuous with eight sub-marginal and eight marginal setae.

Antennule (Fig. 5B). Peduncle with three articles. First article 1.2 times as long as second, with four simple setae and plumose sensory setae; article 2 with four long simple setae and scales in ventral margin; article 3 narrow than others with a group of ventrodistal setae and a long apical seta; flagellum of three articles, distal article with three aesthetascs.

Antenna (Fig. 5C). Peduncle with five articles. Article 2 with scales in ventral margin; articles 3 and 4 sub-equal; article 5 subrectangular, 1.2 times as long as article 4; flagellum with three articles, article 1 longer than the others; distal articles with numerous setae.

Maxilliped (Fig. 5D). Palp with two articles. Article 1 large, 1.3 times as long as wide, internal margin with four setae, external margin with one seta, distal angle with two setae; distal article oblique with three distal wide setae. Endite present, with fine distal setae. 
MaXiLla (Fig. 5E). With seven stout distal teeth.

MANDiBle (Fig. 5F). Symmetrical; palp with two articles, article 1 with a simple distal seta; distal article 1.8 times as long as article 1, whit three mid-distal setae and one long apical. Incisor with three teeth; lacinia mobilis with approximately 13 denticles, sharp molar.

PeREOPOD 1 (Fig. 6A). Subchelate; carpus triangular, apically rounded with a group of distal simple setae; propodus ovate, palm curved, slightly medially convex with a row of 11 short setae; dactylus reaching almost half the palm, internal distal angle with a tooth; unguis slender, reaching the apical margin of the carpus.

Pereopods 2-3 (Fig. 6B-C). Similar in shape and size. Ischium, merus and carpus with numerous ventral simple setae; inner margin of merus denticulate; carpus triangular, partially below the propodus with 2 robust setae on the distal margin; propodus cylindrical, 2 times as long as wide, internal margin with setulated scales, distoventrally one serrated sensory spine and a group of simple setae.

PeREopods 4-7 (Fig. 6D-G). Similar in shape and size. Inner margin of ischium and merus slightly denticulate and numerous simple setae; carpus pentagonal, ventrodistal margin with a single sensory spine and a group of long setae; propodus cylindrical, approximately half the width of the carpus, internal margin with a group of simple setae and setulated scales, ventrodistal margin with a serrate sensory spine and 1-2 pectinate spines; pereopod 7 dactylus with setulated scales on the inner and outer margins. Pereopods 2-7 basis with a long simple seta and plumose sensory setae; merus, carpus and propodus with scales.

Pleopod 1 (Fig. 7A). Protopod with three retinaculae; exopod operculiform, 2.4 times as long as wide, surrounded distal and laterally by 28 plumose setae; endopod almost half as wide as exopod with seven plumose setae.

Pleopod 2 (Fig. 7B). Exopod surrounded distally by 11 plumose setae; endopod surrounded by eight plumose setae.

UROPODAL PROTOPOD (Fig. 7C). Rectangular, 2 times as long as basal width, outer margin with plumose setae.

URopodal ENDOPOD (Fig. 7C). Subtriangular, 1.5 times as long as wide, rounded apex, outer and apical margin with long simple setae and plumose sensory setae.

UROPODAL EXOPOD (Fig. 7D). Auriculiform, dorsal surface with short setae, external margin with 24 simple setae and numerous plumose setae.

Male (dimorphic characters; based on the paratype $\widehat{\partial}$, UMAR-PERA 535)

Antennule (Fig. 7E). Peduncle with three articles; article 2 projected internal distal angle; flagellum robust with four articles, article 1 circular; article 2 with numerous aesthetascs; articles 3 and 4 smaller.

MANDiBLE. Mandibular palp with two articles; distal article with seven long setae.

PEREOPOD 1 (Fig. 7F). Subchelate; palm concave with a strong middle tooth and numerous marginal and mesial setae; distoventral angle of dactylus slightly projected.

Pleopod 2 (Fig. 7G). Similar to the female; exopod surrounded distally by 10 plumose setae; endopod surrounded by seven plumose setae; male appendix emerging from the middle part of the endopod, slightly longer than ramus, apex rounded and slightly bent towards the inside.

\section{Distribution and habitat}

From Puerto Ángel to Huatulco, Oaxaca. In coral, sand and sediment; subtidal (12 m). 

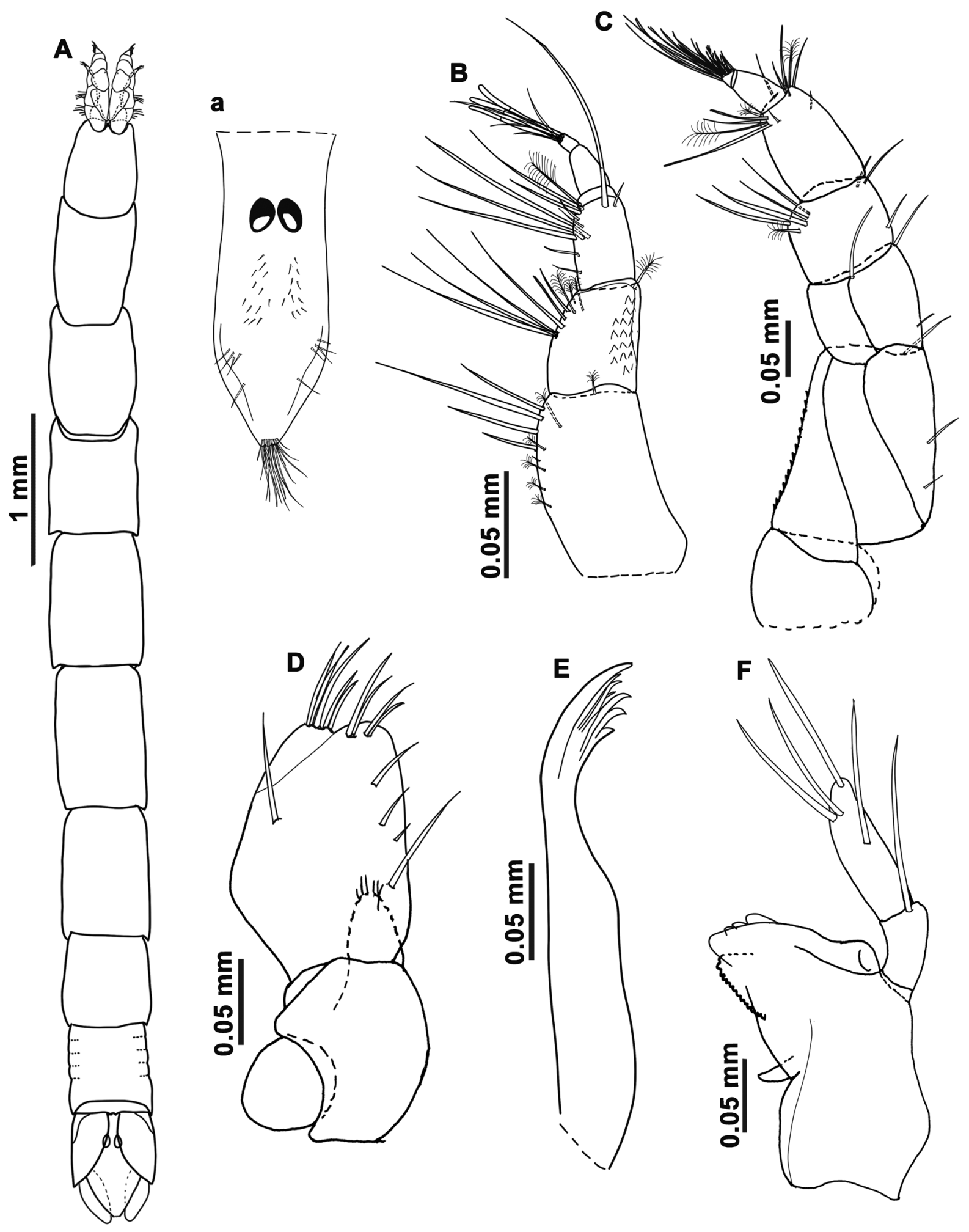

Fig. 5. Cortezura caeca sp. nov., holotype,, , $7.1 \mathrm{~mm}$, Oaxaca, Huatulco, Jicaral Beach (UMAR-PERA 534). A. Habitus and telson (a). B. Antennule. C. Antenna. D. Maxilliped. E. Maxilla. F. Mandible. 

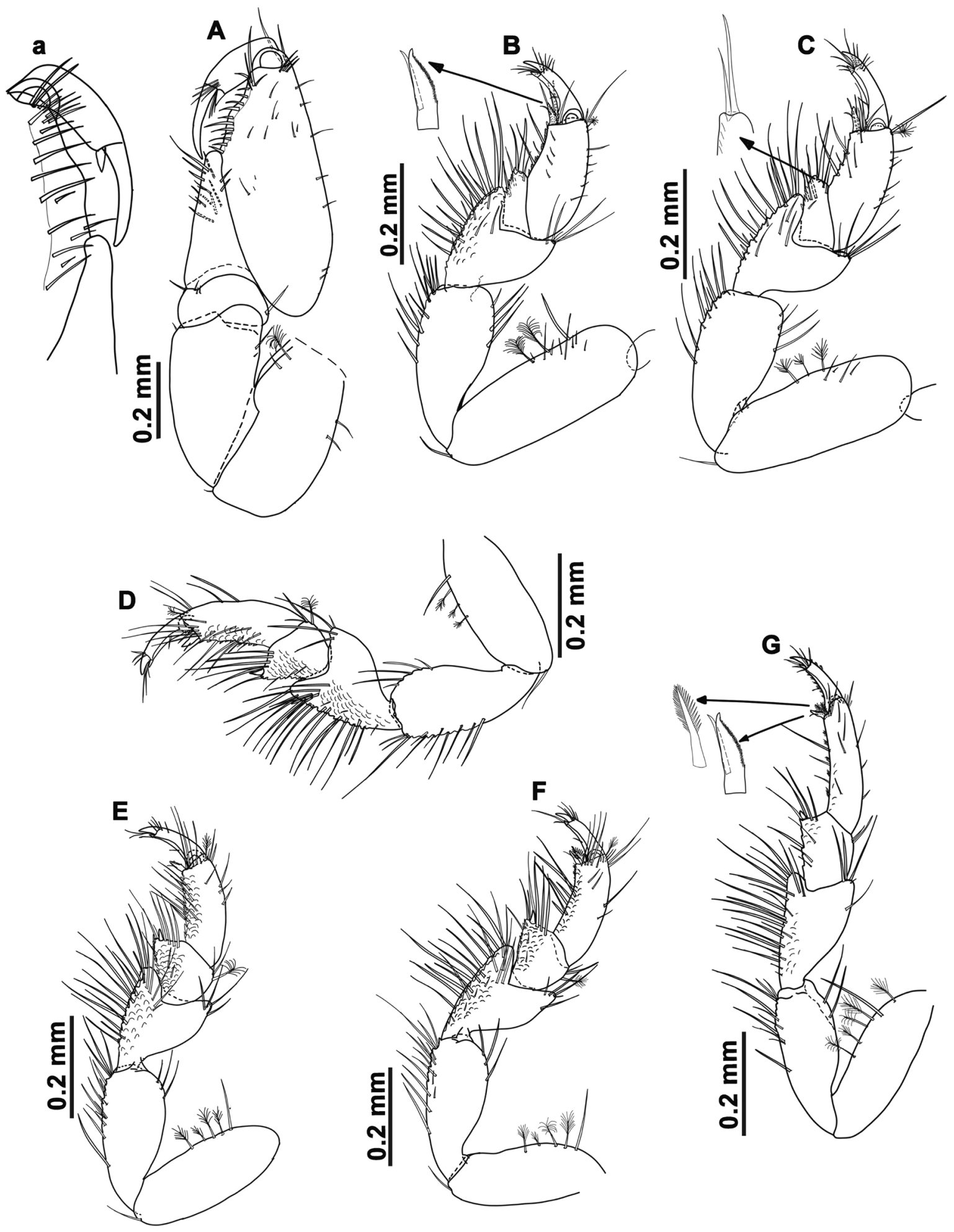

Fig. 6. Cortezura caeca sp. nov., holotype,, , $7.1 \mathrm{~mm}$, Oaxaca, Huatulco, Jicaral Beach (UMAR-PERA 534). A. Pereopod 1 and detail of palm (a). B. Pereopod 2 and detail of the sensory spine. C. Pereopod 3 and detail of carpus. D. Pereopod 4. E. Pereopod 5. F. Pereopod 6. G. Pereopod 7 and detail of the sensory spines. 

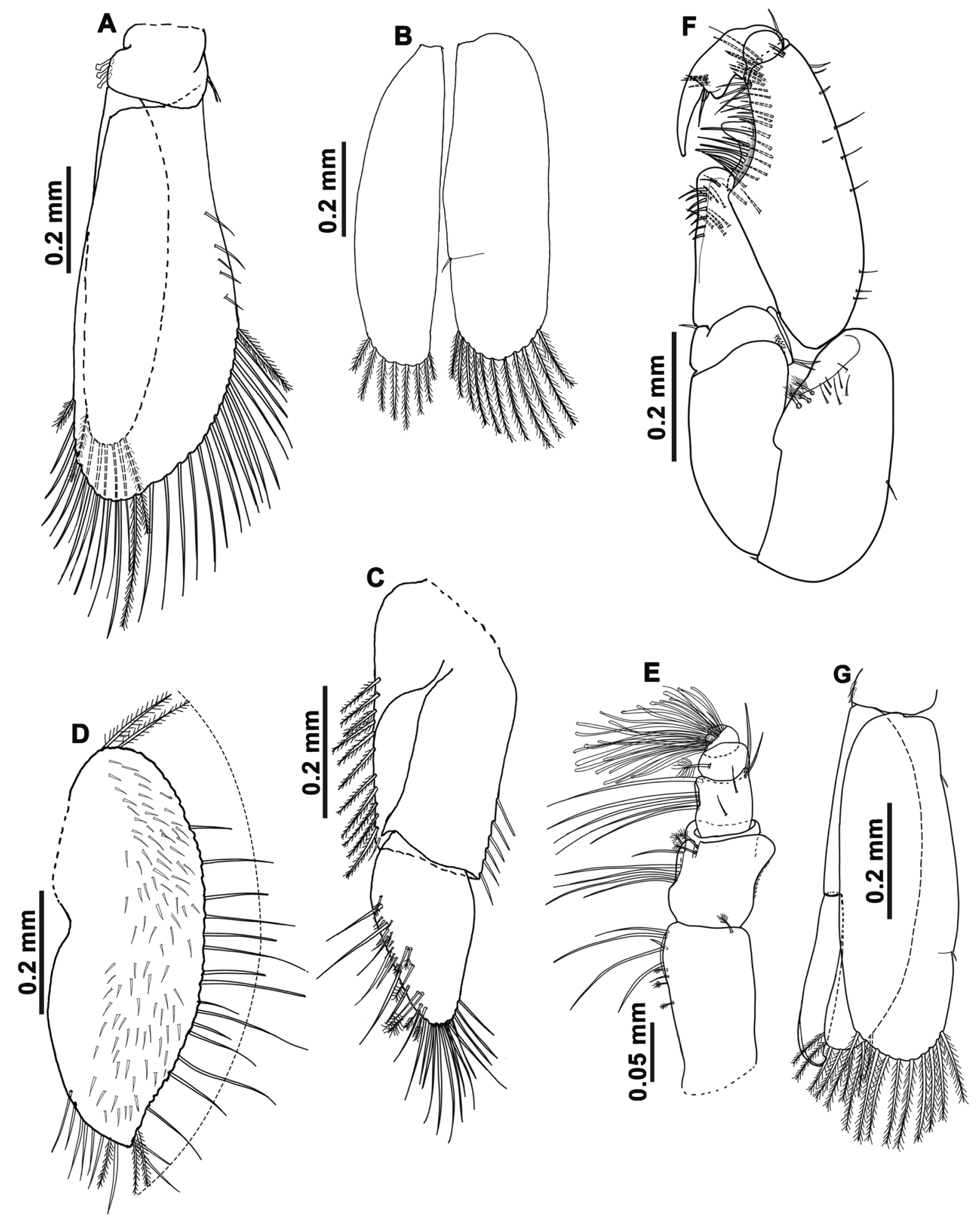

Fig. 7. Cortezura caeca sp. nov. A-D. Holotype,, , $7.1 \mathrm{~mm}$, Oaxaca, Huatulco, Jicaral Beach (UMAR-

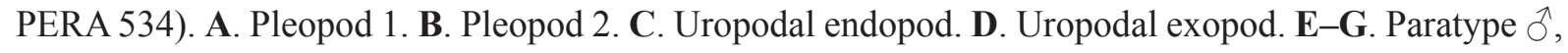
8 mm (UMAR-PERA 535). E. Antennule. F. Pereopod 1. G. Pleopod 2. 


\section{Remarks}

Cortezura caeca sp. nov. differs from the two previously recorded species of this genus, C. penascoensis, described from Puerto Peñasco, Sonora, and C. confixa (Kensley, 1978) described from Cubagua Island, Venezuela, by the following unique characteristics: distal article of the mandibular palp with four medial setae and one apical, lacinia mobilis with 13 denticles, telson with distolateral carina, distal region with eight subapical setae and eight apical. Cortezura caeca sp. nov. is similar to C. penascoensis as follows: (1) form of telson, (2) palm of pereopod 1, and (3) maxilla. However, in C. caeca sp. nov. the distal article of the mandibular palp has four medial setae and one apical, lacinia mobilis with 13 denticles, distally tapered telson and the apex is truncated, pereopods $2-7$ with scales on the merus, carpus and propodus. And in C. penascoensis the distal article of the mandibular palp has six medial setae and one apical, lacinia mobilis presents 8 teeth, pleon with six conspicuous segments. The antennular flagellum of the male of Cortezura caeca sp. nov. has four articles and the palm of pereopod 1 has a strong tooth projected transversally, while $C$. penascoensis has one article on the flagellum, palm of pereopod 1 with tooth projected proximally.

Genus Mesanthura Barnard, 1914

Mesanthura antenniformis sp. nov. urn:lsid:zoobank.org:act:CD29F376-B134-4D1B-9CAD-F163AB552D11

Figs $8-10,20 \mathrm{C}$, Table 1

\section{Etymology}

The name 'antenniformis' refers to the peculiar shape of the second antenna article of this species.

\section{Material examined}

Holotype

MEXICO $\bullet+$ (ovigerous, body length $8 \mathrm{~mm}$ ); Oaxaca, Puerto Ángel, Estacahuite Beach; $15^{\circ} 40^{\prime} \mathrm{N}$, 96²9' W; depth 7 m; 17 Apr. 2008; S. Salazar-Vallejo et al. leg.; dead coral; UMAR-PERA 542.

\section{Paratypes}

MEXICO 1 § (body length $4.1 \mathrm{~mm}$ ); same collection data as for holotype; UMAR-PERA $543 \bullet 6$ 우 (ovigerous), 1 ㅇ, 1 ${ }^{\lambda}$; same collection data as for holotype; UMAR-PERA 544.

\section{Additional material}

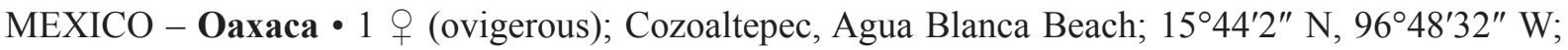
depth shallow water; 2 Apr. 2009; J. León-Robles leg.; fouling algae; UMAR-PERA 539 - 1 q (ovigerous), 1 क; Puerto Ángel Dock; 15³9'56" N, 96²9'27" W; depth 3 m; 12 Jul. 2019; Y. ChávezLópez and A. Pérez-Chávez leg.; tubes of sabellariids; UMAR-PERA 540 • 1 q (ovigerous); Puerto Ángel, Estacahuite Beach; $15^{\circ} 40^{\prime} \mathrm{N}, 96^{\circ} 29^{\prime} \mathrm{W}$; depth 2-4 m; 10 Sep. 2005; J.R. Bastida-Zavala et al.

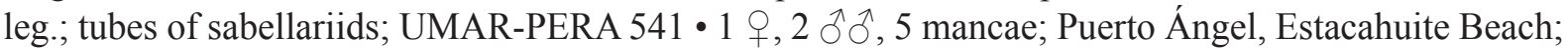
$15^{\circ} 40^{\prime}$ N, 96 $6^{\circ} 29^{\prime}$ W; depth 7 m; 17 Apr. 2008; S. Salazar-Vallejo et al. leg.; rock; UMAR-PERA 545 •

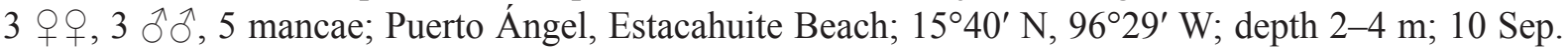
2005; J.R. Bastida-Zavala et al. leg.; coral rock; UMAR-PERA 546.

\section{Description}

Holotype ( $(+$ (ovigerous), UMAR-PERA 542)

Body (Figs 8A, 20C). Length $8 \mathrm{~mm}, 7.7$ times as long as wide, pigmented; cephalon almost half the length of the first pereonite; rostrum prominent and acute, sub-equal to the distal angles of the cephalon; small eyes located on the anterolateral edges of the head, not distinguishable ommatidia; body 
proportion: $\mathrm{C}<1>2<3<4=5>6>7$. Pereonite 7 slightly wider than length; pleonites $1-5$ fused, sub-equal to pereonite 7; telson linguiform, slightly shorter than uropodal endopod, rounded distal region, apex slightly emarginated with six pairs of setae; proximal part with one pair of statocysts.

Antennule (Fig. 8B). Peduncle with three articles. Article 1 rectangular, 1.3 times as long as the second and third together with plumose sensory setae; article 2 half of the 3; flagellum with three articles, sub equal to the last peduncular article, distal article with 5-6 aesthetascs and simple setae.

Antenna (Fig. 8C). Peduncle with five articles. Second article 1.4 times as long as the subsequent peduncular articles; internal angle projected with two simple setae, distal margin with small sinuosities; article 3 partially covered by second article; last article 1.1 times as long as article 4 with simple and sensory plumose setae in the distal region; flagellum with five articles, sub-equal to the length of the last peduncle article, square article with numerous thin setae.

MAXILLIPED (Fig. 8D). Palp with three articles. Article 1 rectangular, half the length of the second with a single ventrodistal seta; distal article small, oblique with six setae, proximal and distal plumose setae, a medial pectinate seta and a simple one.

MaXILla (Fig. 8F). Slender, bent apically with seven teeth.

Mandible (Fig. 8E). Symmetrical; palp with three articles, article 2 cylindrical, 2.2 times as long as the first with a subdistal seta; distal article with 5-6 robust marginal setae; incisor with three teeth; lacinia mobilis with five denticles and small molars.

Pereopod 1 (Fig. 8G). Subchelate; carpus triangular, apical margin rounded with four simple setae; palm slightly convex with four marginal setae, distal margin crenulated; dactylus with a spine in the distoventral angle and a group of setae.

Pereopods 2-3 (Fig. 9A-B). Similar in shape and size. Carpus triangular with three apical setae; propodus elongated, cylindrical, 2.1-2.2 times longer than wide, ventral margin slightly curved with two long setae, distoventral angle with a denticulate sensory spine; dactylus curved with one spine and a group of distal setae.

Pereopods 4-7 (Fig. 9C-F). Similar in shape and size. Carpus trapezoidal with a sensory spine at the ventrodistal margin and three simple setae, external margin with a plumose sensory seta; propodus cylindrical with a denticulate sensory spine at the distal inner angle; dactylus curved. Pereopod 7 propodus with setulated scales and two robust pectinate spines on internal angle. Propodus of all pereopods with plumose sensory setae.

PleOPOD 1 (Fig. 10A). Protopod with five retinaculae; exopod operculiform, almost two times as long as wide, sinuous distal margin, surrounded by 31 plumose setae; endopod sub-equal to the length of the exopod and 0.3 times its width, surrounded apically by 10 plumose setae.

PleOPod 2 (Fig. 10B). Oval and elongated; exopod shorter than endopod, surrounded apically by 10 plumose setae; endopod with seven plumose setae.

UROPODAL PROTOPOD (Fig. 10C). Uropodal protopod 2.3 times as long as endopod with plumose setae on the external margin.

UROPODAL ENDOPOD (Fig. 10C). Oval, distally narrower, 1.6 times as long as wide, margin with simple and plumose setae. 

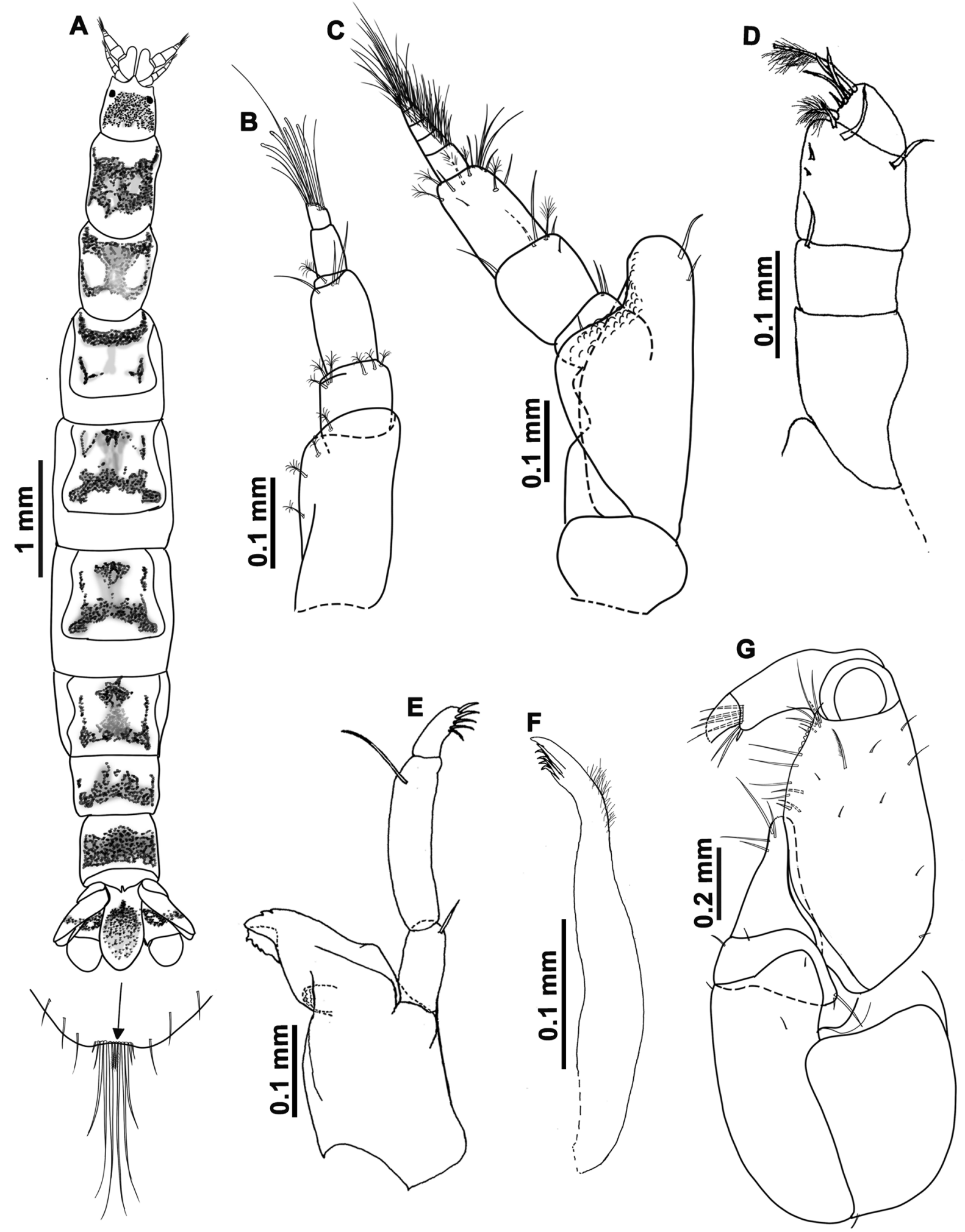

Fig. 8. Mesanthura antenniformis sp. nov., holotype, $q$ (ovigerous), $8 \mathrm{~mm}$, Oaxaca, Puerto Ángel, Estacahuite Beach (UMAR-PERA 542). A. Habitus and detail of the telson. B. Antennule. C. Antenna (right). D. Maxilliped. E. Mandible. F. Maxilla. G. Pereopod 1. 

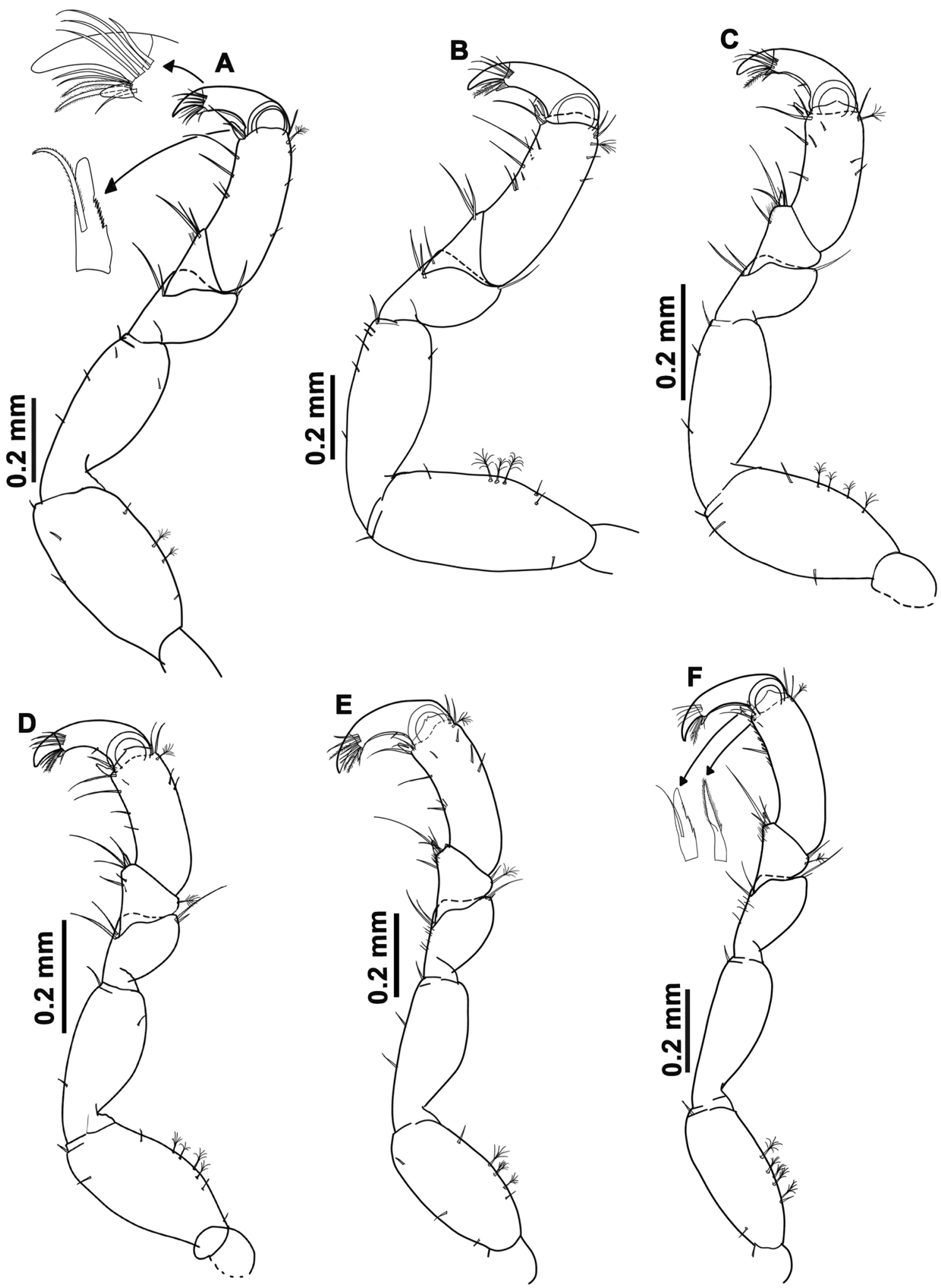

Fig. 9. Mesanthura antenniformis sp. nov., holotype, $q$ (ovigerous), $8 \mathrm{~mm}$, Oaxaca, Puerto Ángel, Estacahuite Beach (UMAR-PERA 542). A. Pereopod 2 and detail of dactylus. B. Pereopod 3. C. Pereopod 4. D. Pereopod 5. E. Pereopod 6. F. Pereopod 7 and detail of the sensory spines. 

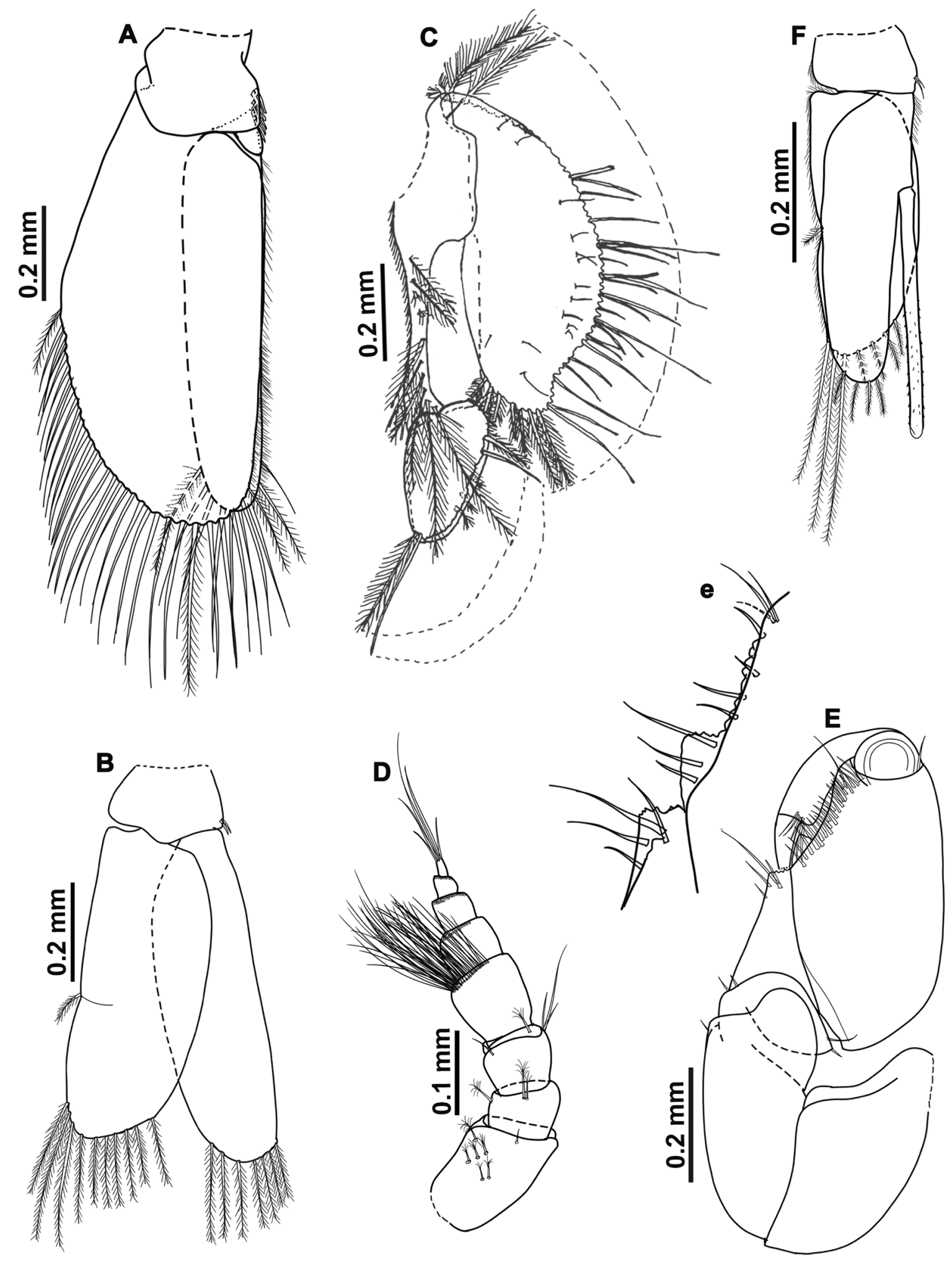

Fig. 10. Mesanthura antenniformis sp. nov. A-C. Holotype, $q$ (ovigerous), $8 \mathrm{~mm}$, Oaxaca, Puerto Ángel, Estacahuite Beach (UMAR-PERA 542). A. Pleopod 1. B. Pleopod 2. C. Uropod. D-F. Paratype, O, 4.1 mm (UMAR-PERA 543). D. Antennule. E. Pereopod 1 and detail of the palm (e). F. Pleopod 2. 
UROPODAL EXOPOD (Fig. 10C). Sub-equal in length to the protopod, oval, distally emarginated, external margin strongly crenulated with plumose and simple setae.

Male (dimorphic characters; based on the paratype ${ }^{\lambda}$, UMAR-PERA 543)

AntennUle (Fig. 10D). Robust; articles 1 and 2 with plumose sensory setae, article 1 rectangular, 2.4 times as long as second; article 2 and 3 sub-equal in length; flagellum with six articles, articles 2-5 with numerous aesthetascs; distal article with a group of long setae.

Pereopod 1 (Fig. 10E). Subchelate; carpus distal part truncated with crenulated margin; palm with a step-like proximal process with robust setae, distal margin crenulated, mesial region with numerous setae.

PleOPOD 2 (Fig. 10F). Exopod shorter than endopod, surrounded apically by seven plumose setae; endopod surrounded apically by four plumose setae; male appendix cylindrical with scales in distal region.

\section{Distribution and habitat}

Central coast of Oaxaca, from Agua Blanca to Estacahuite Beach. In coral, tubes of sabellariids, rocks and algae; intertidal to subtidal $(7 \mathrm{~m})$.

\section{Remarks}

Mesanthura antenniformis sp. nov. differs from previously recorded species of Mesanthura in the following unique characteristics: second article of antenna strongly projected and winding on the distal margin; palm of pereopod 1 straight. Between the three eastern Pacific species (Table 1), M. antenniformis sp. nov. is more similar to M. occidentalis, described from Point Conception, California, by the following characteristics: (1) last article of mandibular palp with five setae, (2) dorsal surface of the telson with some setae; however, differs because in that M. antenniformis sp. nov. has a dense pigmentation pattern, the palm of pereopod 1 is straight with the distal margin crenulate, propodus of pereopod 2 with setulated scales, apical part of the telson slightly emarginated and with six pair of setae, while, M. occidentalis has a slightly pigmented body in a circular pattern, palm of pereopod 1 medially projected, propodus of pereopod 2 with cuticular scales and the telson has eight pairs of setae.

Mesanthura estacahuitensis sp. nov.

urn:lsid:zoobank.org:act:5B34AF3F-DB2A-4B58-9956-32F0361CD6C4

Figs $11-13,20 \mathrm{D}$, Table 1

\section{Etymology}

This species is named after its type locality, Estacahuite Beach, Oaxaca.

\section{Material examined}

Holotype

MEXICO • + (body length $6.8 \mathrm{~mm}$ ); Oaxaca, Puerto Ángel, Estacahuite Beach; $15^{\circ} 40^{\prime} \mathrm{N}, 96^{\circ} 29^{\prime} \mathrm{W}$; depth 2-4 m; 10 Sep. 2005; J.R. Bastida-Zavala et al. leg.; coral rock; UMAR-PERA 547.

\section{Description}

Holotype ( 9 , UMAR-PERA 547)

Body (Figs 11A, 20D). Length $6.8 \mathrm{~mm}, 11.1$ times as long as wide, strongly pigmented; cephalon almost as wide as long, circular eyes, in lateral position, rostrum slightly shorter than lateral angles; body proportion: $\mathrm{C}<1=2>3<4=5>6>7$. Pereonites $2-3$ cylindrical, $4-6$ rectangular, pereonite 7 square; 
Table 1. Comparison between the species of Mesanthura Barnard, 1914 recorded in the Mexican Pacific and Mesanthura antenniformis sp. nov., Mesanthura estacahuitensis sp. nov. from Oaxaca.

\begin{tabular}{|c|c|c|c|c|}
\hline Character / species & $\begin{array}{l}\text { M. occidentalis Menzies \& } \\
\text { Barnard, } 1959\end{array}$ & $\begin{array}{l}\text { M. nubifera } \\
\text { Wägele, } 1984\end{array}$ & $\begin{array}{l}\text { M. antenniformis } \\
\text { sp. nov. }\end{array}$ & $\begin{array}{l}\text { M. estacahuitensis } \\
\text { sp. nov. }\end{array}$ \\
\hline Locality & Point Conception, California & $\begin{array}{l}\text { Turner Island, } \\
\text { Sonora }\end{array}$ & $\begin{array}{l}\text { Estacahuite Beach, } \\
\text { Oaxaca }\end{array}$ & $\begin{array}{l}\text { Estacahuite Beach, } \\
\text { Oaxaca }\end{array}$ \\
\hline Body length & $7.5 \mathrm{~mm}$ & $14 \mathrm{~mm}$ & $8 \mathrm{~mm}$ & $6.8 \mathrm{~mm}$ \\
\hline \multirow{2}{*}{$\begin{array}{l}\text { Last flagellar article } \\
\text { of A1 }\end{array}$} & 3 aesthetascs & 5 aesthetascs & 5-6 aesthetascs & 4 aesthetascs \\
\hline & 7 setae & 4 setae & 5 setae & 3 setae \\
\hline $\begin{array}{l}\text { Distal margin of } \\
\text { second article of } \mathrm{A} 2 \\
\text { peduncle }\end{array}$ & Straight & Straight & $\begin{array}{l}\text { Internal angle } \\
\text { projected }\end{array}$ & Straight \\
\hline $\begin{array}{l}\text { Last article of the } \\
\text { mandibular palp }\end{array}$ & 5 setae & 10 setae & $5-6$ setae & 8 setae \\
\hline Palm of P1 & Medially projected & Medially projected & Straight & Medially projected \\
\hline Propodus of P2 & $\begin{array}{l}\text { Cuticular and setulated } \\
\text { scales }\end{array}$ & Cuticular scales & Setulated scales & Setulated scales \\
\hline Apex of telson & $\begin{array}{l}\text { Rounded with } 8 \text { pairs of } \\
\text { setae }\end{array}$ & $\begin{array}{l}\text { Slightly rounded } \\
\text { with } 9 \text { pairs of setae }\end{array}$ & $\begin{array}{l}\text { Depressed with } 6 \\
\text { pairs of setae }\end{array}$ & $\begin{array}{l}\text { Rounded with } 5 \text { pairs } \\
\text { of setae }\end{array}$ \\
\hline Setae on telson surface & Some shorts & None & Some shorts & None \\
\hline
\end{tabular}

pleonites 1-5 fused, slightly wider than long, 0.9 times as long as pereonite 7, pleonite 6 free with a medial incision on the distal margin; telson linguiform, medially wider, 1.8 times as long as wide, apex broadly rounded with three pairs of long smooth setae and one pair of short plumose setae; one pair of proximal statocysts.

Antennule (Fig. 11B). Peduncle with three articles; article 1 sub-equal in length to articles 2 and 3 together with plumose sensory setae; article 2 sub-square with distal plumose sensory setae; article 3 rectangular, 2.1 times as long as wide; flagellum with three articles, article 1 tiny with one plumose sensory seta; article 2 longest, 0.6 times as long as last peduncle article; article 3 with four aesthetascs and three long simple setae.

Antenna (Fig. 11C). Peduncle with five articles; articles 2-5 with grooved external margin, article 2 sub-square; article 3 shorter than the others; article 4 square; last article 1.3 times as long as article 4 with a group of apical setae; flagellum 0.6 times as long as last peduncle article with four articles decreasing distally and with numerous fine setae.

MAXILLIPED (Fig. 11D). Palp with three articles. Article 1 rectangular, 1.3 times as wide as long with a long seta in the internal distal angle; article 2 with two setae in the inner angle; article 3 oblique, with five setae, one proximal and two distal plumose.

Maxilla (Fig. 11E). Slender, bent distally with five teeth.

MANDible (Fig. 11F). Symmetrical; palp with three articles, article 1 rectangular, almost half the length of second; article 2 with an apical seta; article 3 with eight serrated robust setae. Incisor with three teeth; lacinia mobilis with four denticles and molars rounded. 

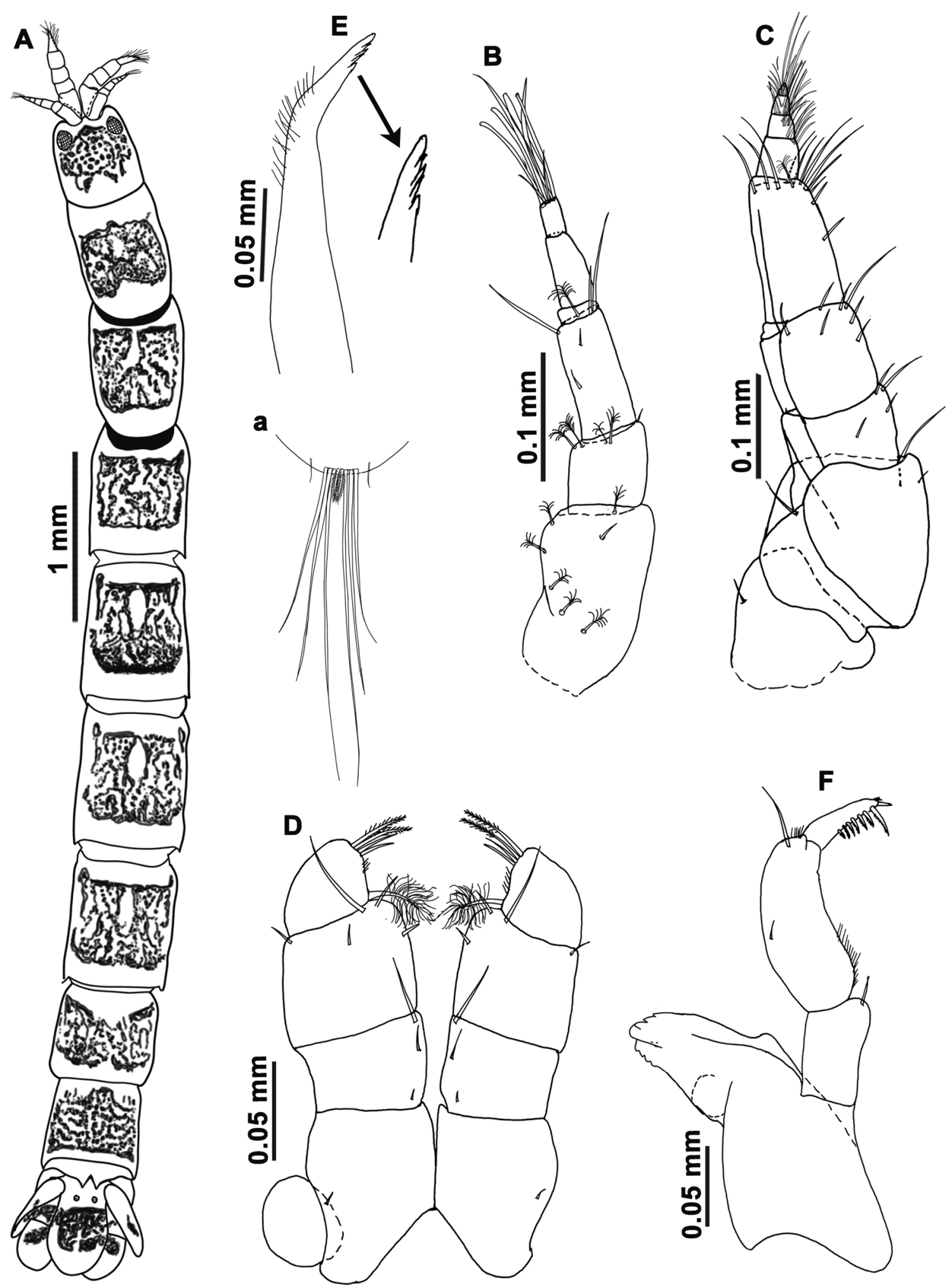

Fig. 11. Mesanthura estacahuitensis sp. nov., holotype,, , $6.8 \mathrm{~mm}$, Oaxaca, Puerto Ángel, Estacahuite Beach (UMAR-PERA 547). A. Habitus and detail of the telson (a). B. Antennule. C. Antenna. D. Maxilliped. E. Maxilla and detail of the distal teeth. F. Mandible. 
PeREOPOD 1 (Fig. 12A). Subchelate; carpus triangular, rounded distally, with three long setae; propodus oval, 2 times as long as wide, palm projected medially with crenulated margin, proximal region with a row of four setae, distal region with a group of smooth setae; dactylus reaching the projection of the palm with two long setae in internal distal angle.

Pereopods 2-3 (Fig. 12B-C). Similar in shape and size. Carpus triangular, with three apical setae; propodus sub-cylindrical, 2.2 times as long as wide in $\mathrm{P} 2$ and 2.7 times as long as wide in P3, internal margin with scales, ventrodistal angle with a denticulate sensory spine; distal margin of dactylus with a spine and a group of smooth and plumose setae.

Pereopods 4-7 (Fig. 12D-G). Similar in shape and size. Carpus sub-pentagonal with a sensory spine on the ventrodistal margin, external margin with a plumose sensory seta; propodus cylindrical, slightly curved, internal margin with setulated scales; ventrodistal angle with a denticulate sensory spine and two pectinate spines in P7; dactylus with a denticle in the internal proximal margin.

Pleopod 1 (Fig. 13A). Protopod with five retinaculae; exopod operculiform, 3.3 times as wide as the endopod, surrounded distally by 26 plumose setae; endopod slightly shorter than exopod, apically rounded with seven plumose setae.

Pleopod 2 (Fig. 13B). Exopod cylindrical, longer than endopod, surrounded distally by eight plumose setae; endopod with five plumose setae.

UROPODAL PROTOPOD (Fig. 13F). Rectangular, 1.6 times as long as wide with a row of plumose setae on the inner margin.

Uropodal ENDOPOD (Fig. 13F). Oval, 1.3 times as long as wide, distal region with smooth and plumose sensory setae.

Uropodal EXOPOD (Fig. 13G). Oval with a strong emargination on the distal region; margin with approximately 20 smooth setae and 30 plumose setae.

\section{Distribution and habitat}

Known only in the type locality, Estacahuite Beach, Oaxaca. In coral rock; subtidal (4 m).

\section{Remarks}

Mesanthura estacahuitensis sp. nov. differs from previously recorded species of Mesanthura by the following unique characteristics: pigmentation pattern, last article of mandibular palp with eight setae, palm of pereopod 1 crenulated and projected medially. Mesanthura estacahuitensis sp. nov. is more similar to M. nubifera, described from Turner Island, Sonora than to the other species (Table 1) as follows: (1) projection to palm of pereopod 1, (2) mandible, (3) shape and dorsal ornamentation of the telson. However, in M. estacahuitensis sp. nov. the distal article of the antennular flagellum has four aesthetascs, flagellum of antenna with four articles, last article of maxillipedal palp with three plumose setae, internal margin of the carpus and propodus of the pereopods $2-7$ with setulated scales and 1-2 simple setae, apical region of the telson with three pairs of simple setae and one pair of plumose setae, while M. nubifera has antennule with five aesthetascs, antennal flagellum with one article, last article of maxillipedal palp with one plumose seta and two pectinate setae, carpus and propodus of the pereopods 2-7 with cuticular scales and up to seven simple setae, and telson with nine pairs of apical setae. 

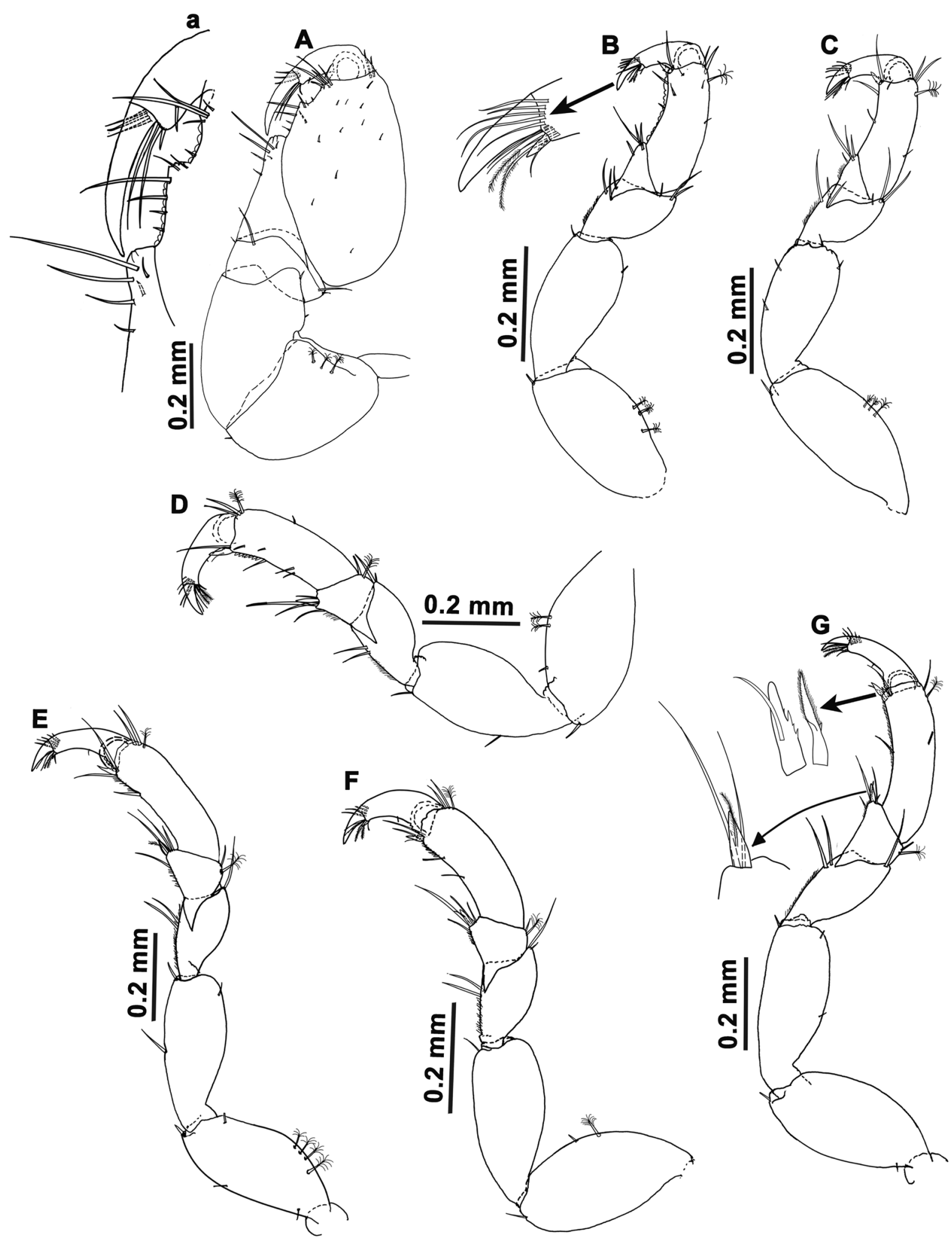

Fig. 12. Mesanthura estacahuitensis sp. nov., holotype,, , $6.8 \mathrm{~mm}$, Oaxaca, Puerto Ángel, Estacahuite Beach (UMAR-PERA 547). A. Pereopod 1 and detail of the palm (a). B. Pereopod 2 and detail of the dactylus. C. Pereopod 3. D. Pereopod 4. E. Pereopod 5. F. Pereopod 6. G. Pereopod 7 and detail of carpus and sensory spines. 

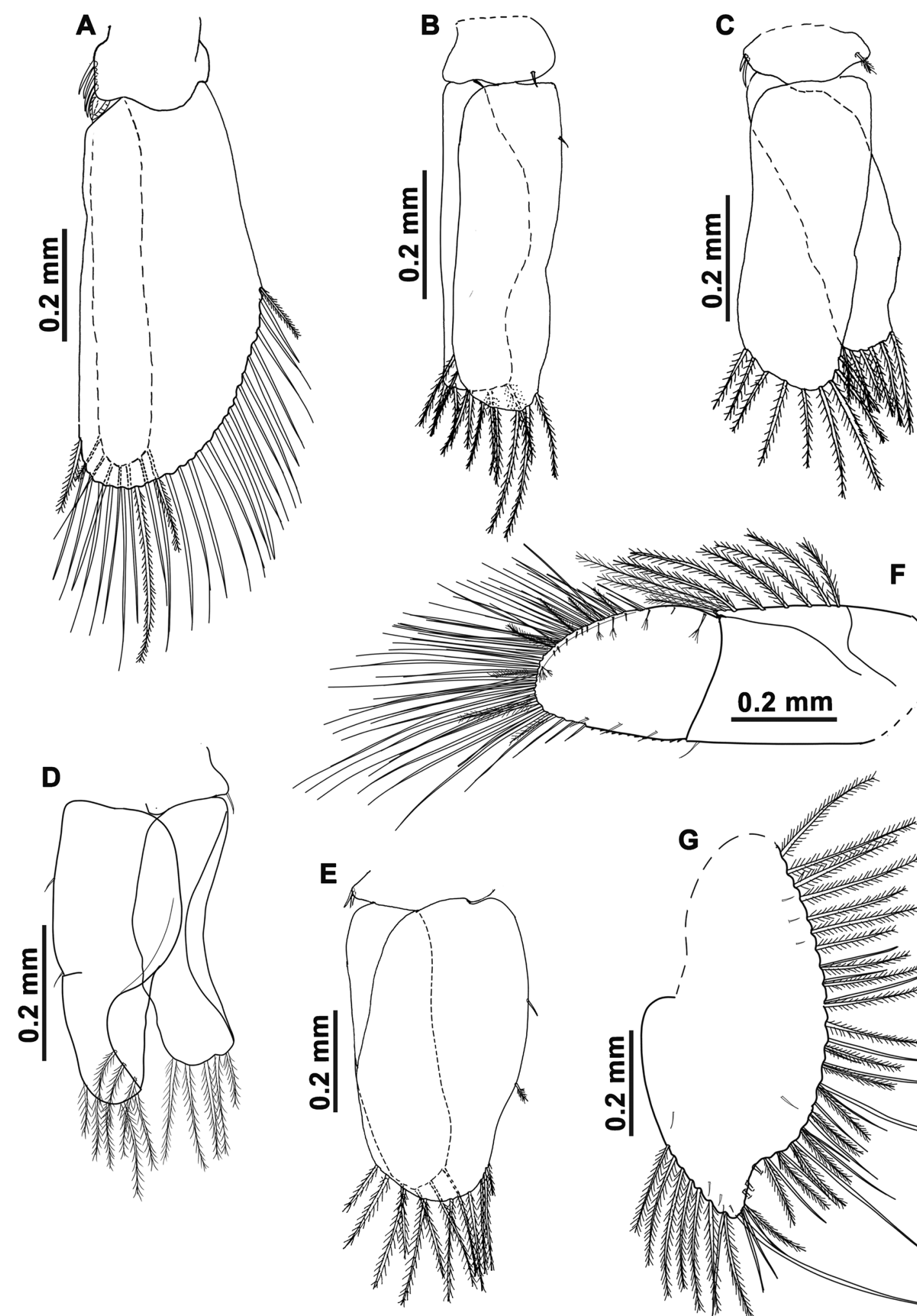
Genus Skuphonura Barnard, 1925

Skuphonura oaxaquensis sp. nov. urn:1sid:zoobank.org:act:5739A519-7093-496A-8F3C-9EEAC092E241

Figs 14-16, 20E, Table 2

\section{Etymology}

This species is named after Oaxaca, the Mexican State where the specimens were collected.

\section{Material examined}

Holotype

MEXICO • + (body length $7.9 \mathrm{~mm}$ ); Oaxaca, Puerto Ángel, Estacahuite Beach; $15^{\circ} 40^{\prime} \mathrm{N}, 96^{\circ} 29^{\prime} \mathrm{W}$; depth 2-4 m; 10 Sep. 2005; J.R. Bastida-Zavala et al. leg.; coral rock; UMAR-PERA 548.

\section{Paratypes}

MEXICO 1 त (body length $7.3 \mathrm{~mm}$ ); same collection data as for holotype; UMAR-PERA 549 • 12 우, 1 ○ं; same collection data as for holotype; UMAR-PERA 550.

\section{Description}

Holotype ( 9 , UMAR-PERA 548)

Body (Figs 14A-B, 20E). Length $7.9 \mathrm{~mm}, 8.4$ times as long as wide with pigment in the cephalon and margins of each somite; body proportion: $\mathrm{C}<1>2 \geq 3<4>5>6>7$. Cephalon 1.2 times as long as wide, rostrum as long as the lateral angles of cephalon, base of the mouthparts with two sharp spines. Pereonite 7 rectangular, 1.3 times as wide as long; pleonites 1-5 fused, broadened distally, slightly longer than pereonite 7; telson linguiform, narrow distal region, mid-distal region with a group of seven setae, apex slightly excavated with three pairs of setae; a pair of the statocysts.

Antennule (Fig. 14D). Peduncle with three articles. Articles 1 and 2 with plumose sensory setae; article 2 rectangular, slightly more than half the length of the first with six long distolateral setae; article 3 sub-equal in length to second with one long seta in the external distal angle and two in the internal one; flagellum with three articles, last tiny article with three aesthetascs and two smooth setae.

Antenna (Fig. 14E). Peduncle with five articles. Article 2 with ventrodistal angle projected to article 3; flagellum with four articles with numerous thin setae.

MAXILLIPED (Fig. 14F). Palp with three articles; article 1 with concave external margin; article 2 larger to the others with sinuous internal margin; distal article subcircular with a row of distal setae.

MaXiLla (Fig. 14G). With eight distal teeth.

MANDiBle (Fig. 14H). Symmetrical; palp with three articles, article 1 sub-equal in length to the second with a long pectinate seta; article 2 with three pectinate setae and setulated scales in dorsal margin; article 3 small, 0.4 times as long as second, with four distal setae; incisor with four teeth; lacinia mobilis with 11 denticles and molars with two rounded tubercles.

Pereopod 1 (Fig. 15A). Subchelate; basis with dorsodistal angle lobate; carpus subtriangular, distal angle projected transversally; palm concave with a strong proximal tooth; proximal margin with six setae, distal margin with eight setae; internal margin of dactylus slightly concave with a cuticular ridge; unguis slightly more than half the length of dactylus with a slight curvature distally. 


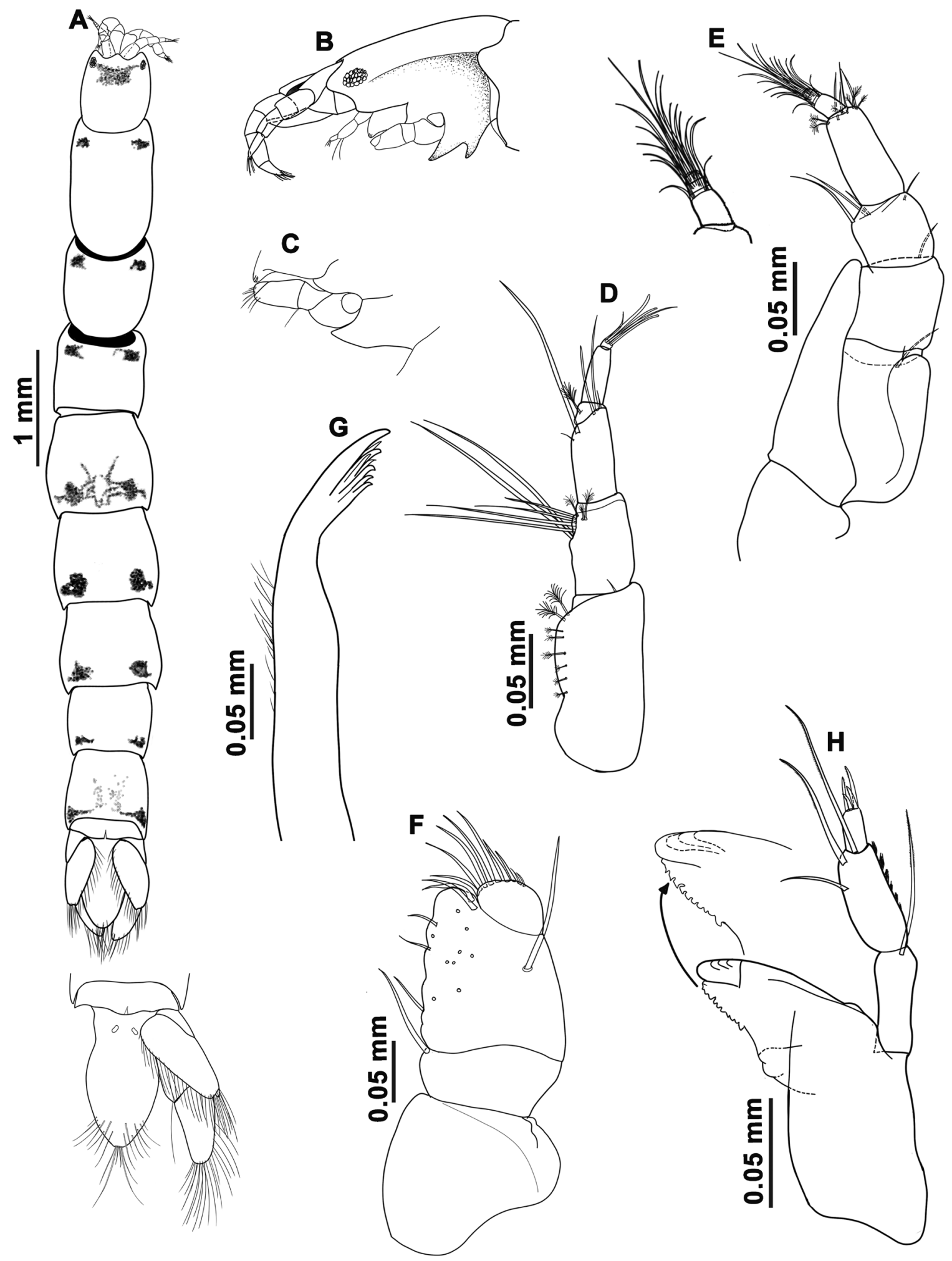

Fig. 14. Skuphonura oaxaquensis sp. nov. A-B, D-H. Holotype,, , $7.9 \mathrm{~mm}$, Oaxaca, Puerto Ángel, Estacahuite Beach (UMAR-PERA 548). A. Habitus and detail of the pleotelson. B. Cephalon. C. Paratype, Ô, 7.3 mm (UMAR-PERA 549). Base of mouthparts. D. Antennule. E. Antenna and detail of flagellum. F. Maxilliped. G. Maxilla. H. Mandible and detail of the lacinia. 

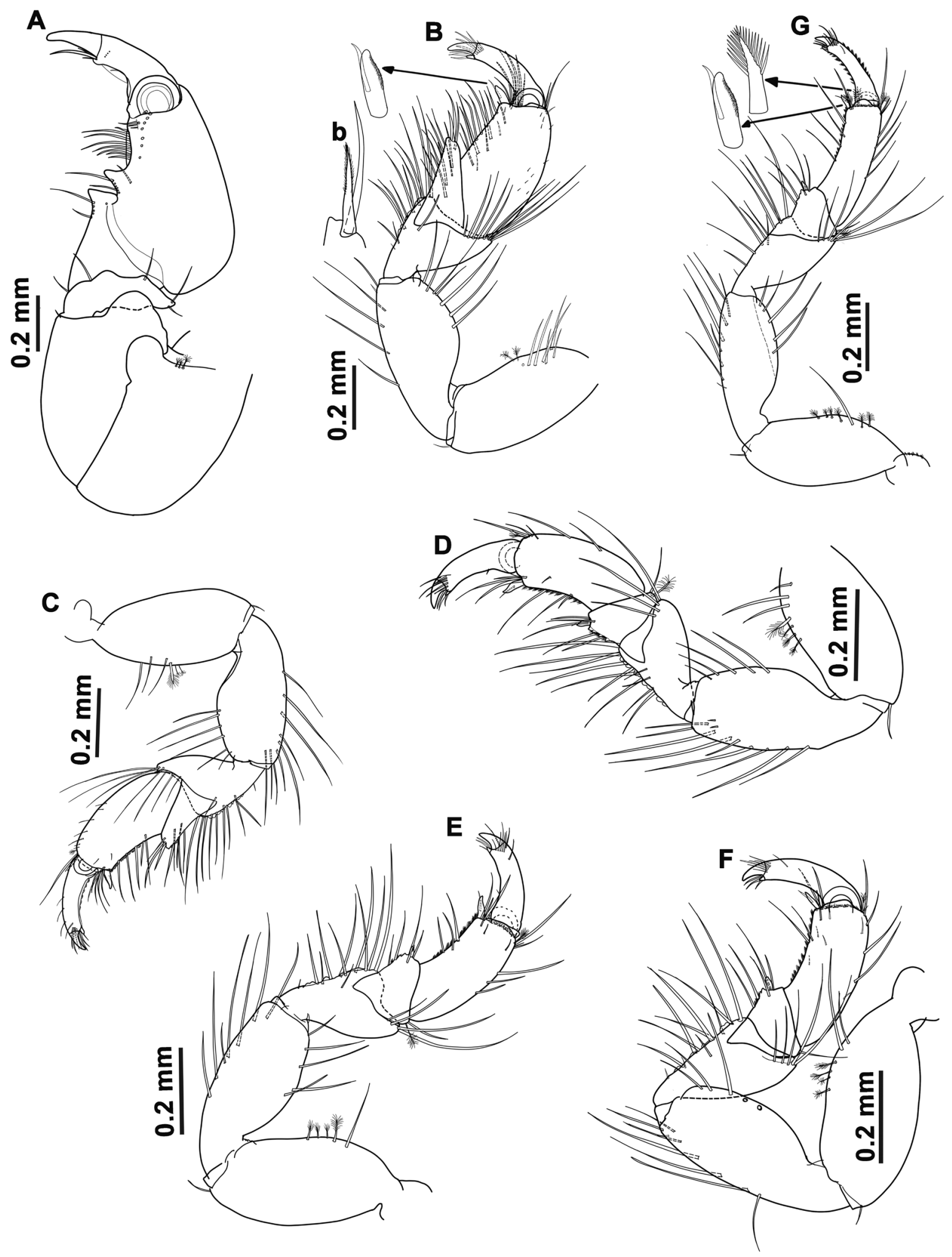

Fig. 15. Skuphonura oaxaquensis sp. nov., holotype, $\subsetneq, 7.9 \mathrm{~mm}$, Oaxaca, Puerto Ángel, Estacahuite Beach (UMAR-PERA 548). A. Pereopod 1. B. Pereopod 2 and detail of the carpus (b) and sensory spine. C. Pereopod 3. D. Pereopod 4. E. Pereopod 5. F. Pereopod 6. G. Pereopod 7 and detail of the sensory spines.. 
Pereopods 2-3 (Fig. 15B-C). Similar in shape and size. Merus internal margin with cuticular ridges and numerous setae; carpus triangular, distal margin with a denticulate seta; palm with numerous setae and setulated scales, ventral angle with a denticulate sensory spine and a group of smooth setae.

Pereopods 4-6 (Fig. 15D-F). Similar in shape and size. Merus margin with cuticular ridges; carpus subtriangular, truncated distally with a simple sensory spine and simple setae; propodus cylindrical, 2-2.1 times as long as wide in P4 and P5, 2.3 in P6, internal margin with setulated scales and simple setae, ventrodistal angle with a denticulate sensory spine and simple setae.

Pereopod 7 (Fig. 15G). Slenderer than the preceding ones, propodus 3.3 times as long as wide, ventrodistal margin with setulated scales and one denticulate sensory spine and two pectinate spines; lateral margins of dactylus with setulated scales.

Pereopods 2-7. With smooth and plumose sensory setae at the basis.

Pleopod 1 (Fig. 16A). Protopod with three retinaculae; exopod operculiform, 2.2 times as long as wide, surrounded distally by 40 plumose setae; endopod 0.7 times the length of exopod, surrounded distally by five plumose setae.

PleOPOD 2 (Fig. 16B). Oval and elongated; exopod 2.8 times as long as wide, surrounded distally by 12 plumose setae; endopod slightly shorter than exopod, surrounded distally by eight plumose setae.

UROPODAL PROTOPOD (Fig. 16C). Rectangular, 1.7 times as long as wide, 1.2 times as long as endopod, external margin with plumose setae, ventrodistal angle with a long seta.

URopodal ENDOPOD (Fig. 15C). Conical, 1.9 times as long as basal width, apically rounded, external margin with numerous long setae.

Uropodal EXOPOD (Fig. 16D). Suboval with a distal notch, margin with 17 long smooth setae and approximately 55 plumose setae.

Male (dimorphic characters; based on the paratype $\widehat{\delta}$, UMAR-PERA 549)

BoDy. Mid-region of the cephalon (Fig. 14C) with a poorly developed spine.

Antennule (Fig. 16E). Peduncle with three articles; article 1 and 2 with plumose sensory setae; article 2 with six long setae in the external distal angle; flagellum with nine articles, distal article with three aesthetascs.

PeREopod 1 (Fig. 16F). Subchelate; carpus triangular, distally produced in a narrow triangular process; propodus oval, palm straight with a triangular proximal process, accompanied by eight setae; dactylus 1.4 times as long as unguis, distoventral angle with a small spine.

Pleopod 2 (Fig. 16G). Endopod and exopod sub-equal in length; exopod surrounded distally by 11 plumose setae; endopod surrounded distally by seven plumose setae; male appendix thin, longer than the branches, emerging from the middle proximal part of the endopod, ending in a pointed apex.

\section{Distribution and habitat}

Known only from the type locality, Estacahuite Beach, Oaxaca. In coral rock; subtidal (4 m). 

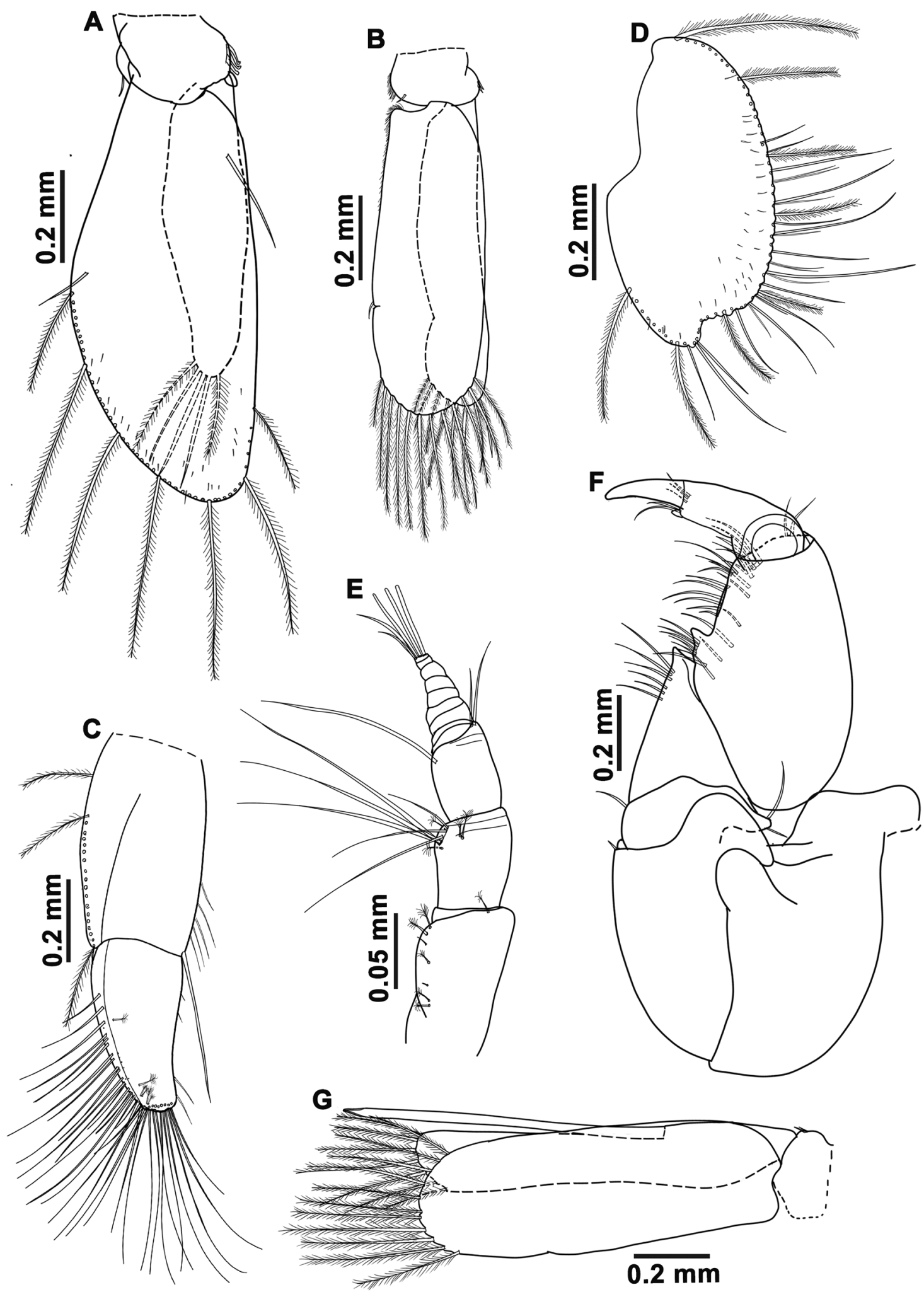

Fig. 16. Skuphonura oaxaquensis sp. nov. A-D. Holotype, $\uparrow, 7.9 \mathrm{~mm}$, Oaxaca, Puerto Ángel, Estacahuite Beach (UMAR-PERA 548). A. Pleopod 1. B. Pleopod 2. C. Uropodal endopod. D. Uropodal exopod. E-G. Paratype, ô, 7.3 mm (UMAR-PERA 549). E. Antennule. F. Pereopod 1. G. Pleopod 2. 
Table 2. Comparison between Skuphonura oaxaquensis sp. nov. and the closest species of genera.

\begin{tabular}{|c|c|c|c|c|}
\hline Character / species & $\begin{array}{l}\text { S. ecuadorensis } \\
\text { Kensley, } 1980\end{array}$ & $\begin{array}{l}\text { S. itapuca } \\
\text { Kensley, } 1980\end{array}$ & $\begin{array}{l}\text { S. kensleyi Brusca \& } \\
\text { Müller, } 1991\end{array}$ & $\begin{array}{l}\text { Skuphonura } \\
\text { oaxaquensis sp. nov. }\end{array}$ \\
\hline Locality & La Libertad, Ecuador & $\begin{array}{l}\text { Nichteroy, Rio de } \\
\text { Janeiro, Brazil }\end{array}$ & $\begin{array}{l}\text { Santa Marta, Punta de } \\
\text { Betin, Colombia }\end{array}$ & $\begin{array}{l}\text { Estacahuite Beach, } \\
\text { Oaxaca }\end{array}$ \\
\hline Body length & $7.2 \mathrm{~mm}$ & $9.3 \mathrm{~mm}$ & $5.7 \mathrm{~mm}$ & $7.9 \mathrm{~mm}$ \\
\hline Body & Not pigmented & Not pigmented & Reticulated pigment & Partially pigmented \\
\hline $\begin{array}{l}\text { Anterior length of } \\
\text { cephalon }\end{array}$ & $\begin{array}{l}\text { Wider than the } \\
\text { posterior }\end{array}$ & $\begin{array}{l}\text { Subequal as the } \\
\text { posterior }\end{array}$ & As wide as the posterior & $\begin{array}{l}\text { As wide as the } \\
\text { posterior }\end{array}$ \\
\hline $\begin{array}{l}\text { Medioventral } \\
\text { processes of cephalon }\end{array}$ & $\begin{array}{l}1 \text { conical spine, } \\
1 \text { blunt tubercle }\end{array}$ & 2 conical spine & - & 2 conical spine \\
\hline $\begin{array}{l}\text { Articles of flagellum } \\
\text { A1 }\end{array}$ & 1 & 1 & 3 & 3 \\
\hline Aesthetascs & 2 & 2 & 1 & 3 \\
\hline $\begin{array}{l}\text { Article of flagellum } \\
\text { A2 }\end{array}$ & 1 & 1 & 1 & 4 \\
\hline $\begin{array}{l}\text { Lacinia mobilis } \\
\text { denticles }\end{array}$ & 11 & 9 & 6 & 10 \\
\hline $\begin{array}{l}\text { Setae of the last } \\
\text { article of mandibular } \\
\text { palp }\end{array}$ & 3 & 3 & 3 & 4 \\
\hline $\begin{array}{l}\text { Setae of the } 2 \text { article } \\
\text { of mandibular palp }\end{array}$ & 4 & 3 & 2 & 3 \\
\hline Carpus of P1 & Well produced & Slightly produced & Well produced & Well produced \\
\hline Palm spines of $\mathrm{P} 1$ & 2 distal & $\begin{array}{l}1 \text { large proximal and } \\
1 \text { small distal }\end{array}$ & 1 small medial & 1 large proximal \\
\hline
\end{tabular}

\section{Remarks}

Skuphonura oaxaquensis sp. nov., and three other species of genus: S. kensleyi Brusca \& Müller, 1991, S. itapuca Kensley, 1980 and S. lindae Menzies \& Kruczynski, 1983 (Table 2), share the following two characters: anterior margin of the cephalon as wide as the posterior margin and the anterolateral lobes are sub-equal to the rostral process, while in S. ecuadorensis Kensley, 1980 and S. laticeps Barnard, 1925 , the anterior margin of the cephalon is wider than the posterior and the lobes are longer than the rostral process.

Skuphonura itapuca, described from Nichteroy, Rio de Janeiro, Brazil, is the closest species to $S$. oaxaquensis sp. nov. by the following characteristics: (1) absence of a mid-ventral spine in the pereonite 1, (2) mid-ventral region of cephalon with two processes, (3) second article of mandibular palp with three long setae. However, in S. oaxaquensis sp. nov. the body is partially pigmented, cephalon slightly wider medially, flagellum of antennule with three articles, distal article with three aesthetascs, flagellum of antenna with four articles, and carpus of pereopod 1 is externally projected and palm with one proximal tooth; while, $S$. itapuca lacks pigment, anterior margin of the cephalon is slightly wider than the posterior, flagellum of antennule with two article and two distal aesthetascs, flagellum of antenna with one article, carpus of pereopod 1 projected apically and palm with one proximal and one distal spine. 
Skuphonura oaxaquensis sp. nov. and S. kensleyi, described from Santa Marta, Punta de Betín, Colombian Caribbean, are similar by the following characteristics: (1) pigmentation pattern, (2) cephalon slightly wider medially, (3) antennular flagellum, (4) carpus of pereopod 1. However, in S. kensleyi the pereonites and pleon have reticulated pigmentation, antennular flagellum with one aesthetasc, antennal flagellum with one article, the second article of the mandibular palp with two distal setae and three proximal setae, lacinia mobilis with six denticles, and palm of the pereopod 1 has a medial tooth; while, in S. oaxaquensis sp. nov. the reticulated pigmentation is partial in pereonite 4 and pleon.

Skuphonura oaxaquensis sp. nov. differs from the preceding species by the following unique characteristics: (1) body pigmentation, (2) last article of mandibular palp with four setae, (3) lacinia mobilis with 11 denticles, (4) inner margin of the second article of maxillipedal palp sinus, and (5) palm of pereopod 1 with a proximal tooth.

Genus Tinggianthura Chew, Abdul-Rahim \& Haji Ross, 2014

Tinggianthura mexicana sp. nov. urn:1sid:zoobank.org:act:0B9D9534-1B0A-4931-8929-1B0933C54C7D

Figs $17-19,20 \mathrm{~F}$, Table 3

\section{Etymology}

This species is named after Mexico, the country where the second species of the genus is described.

\section{Material examined}

\section{Holotype}

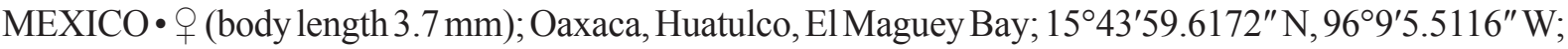
depth 1 m; 4 Jul. 2007; B. Martínez-Guerrero et al. leg.; algae and sediment; UMAR-PERA 561.

\section{Paratypes}

MEXICO $\bullet 1 \hat{~} \hat{~(b o d y ~ l e n g t h ~} 3.9 \mathrm{~mm}$ ); same collection data as for holotype; UMAR-PERA $562 \cdot 3$ q $q$, $2 \partial^{\lambda}$; same collection data as for holotype; UMAR-PERA 563.

\section{Additional material}

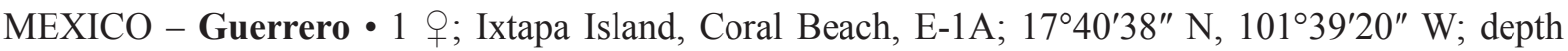
1.5 m; 19 Sep. 2007; M.S. García-Madrigal et al. leg.; coral rock; UMAR-PERA $551 \bullet 1$ ơ; same locality data as for preceding; depth 6 m; 19 Sep. 2007; M.S. García-Madrigal et al. leg.; algae; UMAR-

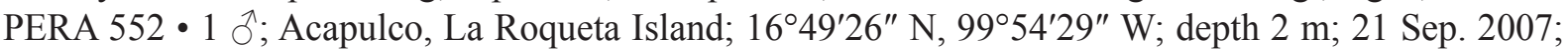
M.S. García-Madrigal et al. leg.; tubes of sabellariids; UMAR-PERA 553. - Oaxaca • 1 , 1 §; Zipolite,

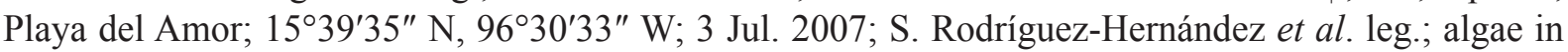

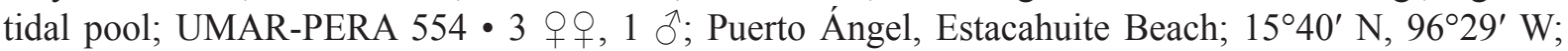

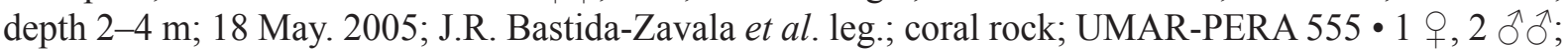
same locality data as for preceding; 10 Sep. 2005; J.R. Bastida-Zavala et al. leg.; UMAR-PERA 556

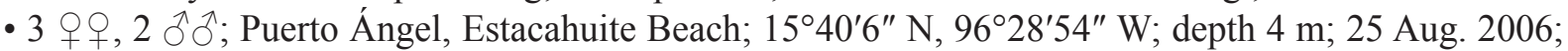
J.R. Bastida-Zavala et al. leg.; coral rock; UMAR-PERA 557 • 3 o 9 ; Puerto Ángel, La Boquilla Bay; $15^{\circ} 40^{\prime} 59^{\prime \prime}$ N, 96 27'54" W; 3 Nov. 2007; J. Medina-Elizalde and E. Serrano-Figueroa leg.; shallow

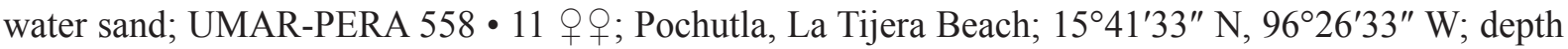
2-4 m; 30 Apr. 2005; J.R. Bastida-Zavala et al. leg.; coral rock; UMAR-PERA $559 \bullet 1$ ठ̊; same locality data as for preceding; 17 Sep. 2006; J.R. Bastida-Zavala et al. leg.; UMAR-PERA 583 • 1 q; Huatulco, San Agustín Bay; 1541'27" N, 96 14'15" W; 24 Feb. 2007; M.S. García-Madrigal et al. leg.; shallow water coral algae; UMAR-PERA 560. 


\section{Description}

Holotype ( 9 , UMAR-PERA 561)

Body (Figs 17A, 20F). Length $3.7 \mathrm{~mm}, 9.9$ times as long as wide with a pigment line on the cephalon and pereonites 2-6; body proportion: $\mathrm{C}<1>2<3<4=5>6>7$. Cephalon as long as wide, 0.4 times as long as pereonite 1, rostrum as long as lateral angles; eyes small, rounded. Pereonite 1 long compared to the others, pereonite 7 the shortest. Pleon sub-square, 1.4 times as long as pereonite 7; pleonites 1-5 fused with ventrolateral suture lines, distal margin of pleonite 6 emarginated. Telson linguiform, 2.3 times as long as wide with a pair of proximal statocysts; dorsal surface squamous with a row of distal and medial setae, apex with a small excavation with three pairs of setae, two short and one long.

Antennule (Fig. 17B). Peduncle with three articles. Article 1 and 2 with plumose sensory setae; article 2 with four long setae; article 3 with four long setae on the external margin and one on the internal distal angle; flagellum with three articles, second article 3.6 times as long as third, article 3 with three aesthetascs.

Antenna (Fig. 17C). Peduncle with five articles. Article 2 larger compared to the others, 1.2 times as long as wide and 2.2 times as long as the third one, article 3 sub-equal to article 4 , article 4 square with simple and sensory setae in the internal distal angle, last article 1.3 times as long as article 4, distal margin with a group of smooth and sensory plumose setae; flagellum with three articles, article 1 visible, distal articles smaller, difficult to distinguish with numerous setae.

Maxilliped (Fig. 17D). Palp with two articles, first article with one proximal seta, one medial and two distal; article 2 oblique with five setae. Endite absent.

MaXiLla (Fig. 17E). With six distal teeth.

Mandible (Fig. 17F). Symmetrical; palp with three articles, article 1 with one seta; article 2 with four long setae; article 3 reduced, 0.25 times the length of the article 1 with a robust denticulate seta; incisor with three teeth; lacinia mobilis with four denticles and molar blunt.

Pereopod 1 (Fig. 18A). Subchelate; carpus triangular, apically rounded with a cuticular ridge and seven simple setae; propodus oval, 2 times as long as wide, palm convex with a cuticular ridge and a row of eight setae; dactylus with a long seta in the ventrodistal angle; unguis longer than dactylus.

Pereopods 2-3 (Fig. 18B-C). Similar in shape and size. Carpus triangular with an apical denticle and two robust setae; propodus 1.9 times as long as wide, internal margin with 4-5 simple setae and one ventrodistally denticulate sensory spine, dorsal margin with a simple seta.

Pereopods 4-6 (Fig. 18D-F). Similar in shape and size. Merus inner margin denticulate; carpus trapezoid, ventrodistal margin with a simple sensory spine and a plumose sensory seta in the dorsal margin; propodus cylindrical, internal margin with setulated scales and two simple setae, ventrodistal angle with one denticulate sensory spine.

Pereopod 7 (Fig. 18G). Similar to pereopods 4-6, slender. Propodus 2.6 times as long as wide, ventral margin with one simple seta and setulated scales, ventrodistal angle with one denticulate sensory spine and two pectinate spines; dactylus with setulated scales on ventral and dorsal margins. Basis of all pereopods with simple and plumose sensory setae.

Pleopod 1 (Fig. 19A). Protopod with three retinaculae and two setae on the inner margin; exopod operculiform, 2.1 times as long as wide and 2.6 times as wide as endopod, internal proximal margin 

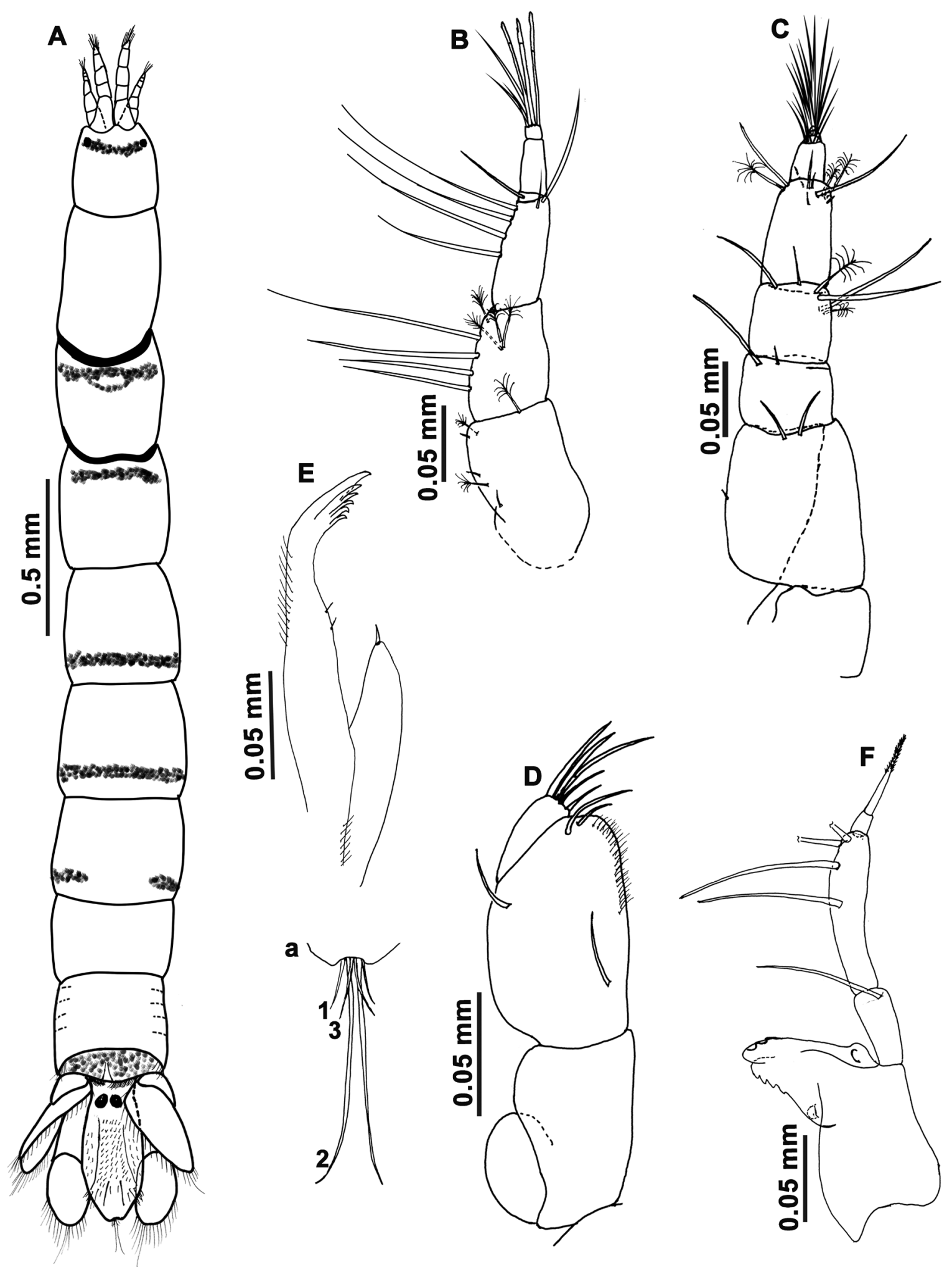

Fig. 17. Tinggianthura mexicana sp. nov., holotype,,$+ 3.7 \mathrm{~mm}$, Oaxaca, Huatulco, El Maguey Bay (UMAR-PERA 561). A. Habitus and detail of the telson (a) (the numbers indicate the pairs of setae). B. Antennule. C. Antenna. D. Maxilliped. E. Maxilla. F. Mandible. 


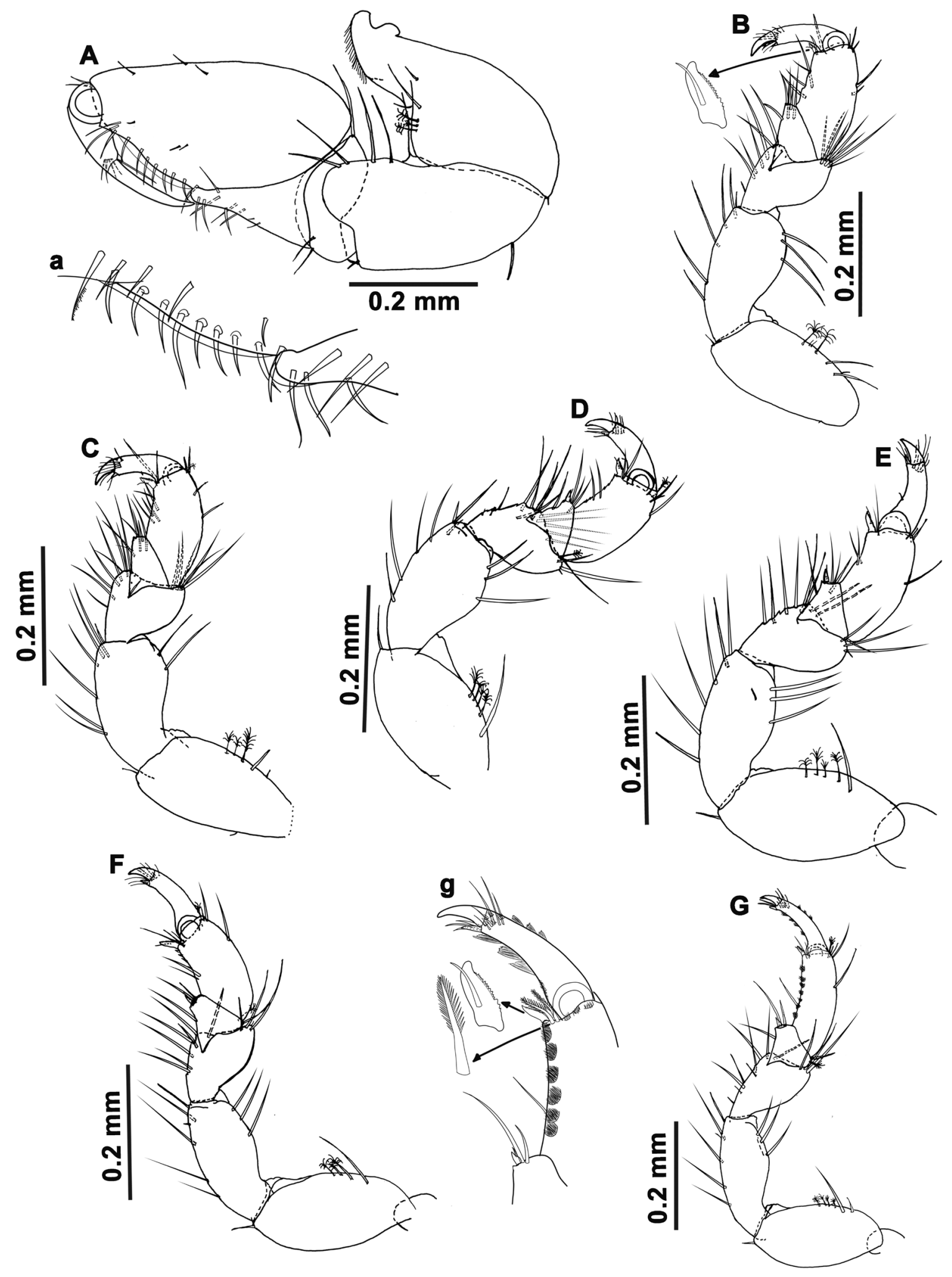

Fig. 18. Tinggianthura mexicana sp. nov., holotype,,$+ 3.7 \mathrm{~mm}$, Oaxaca, Huatulco, El Maguey Bay (UMAR-PERA 561). A. Pereopod 1 and detail of the palm (a). B. Pereopod 2 and detail of the sensory spine. C. Pereopod 3. D. Pereopod 4. E. Pereopod 5. F. Pereopod 6. G. Pereopod 7 and detail of propodus and dactylus $(\mathrm{g})$. 

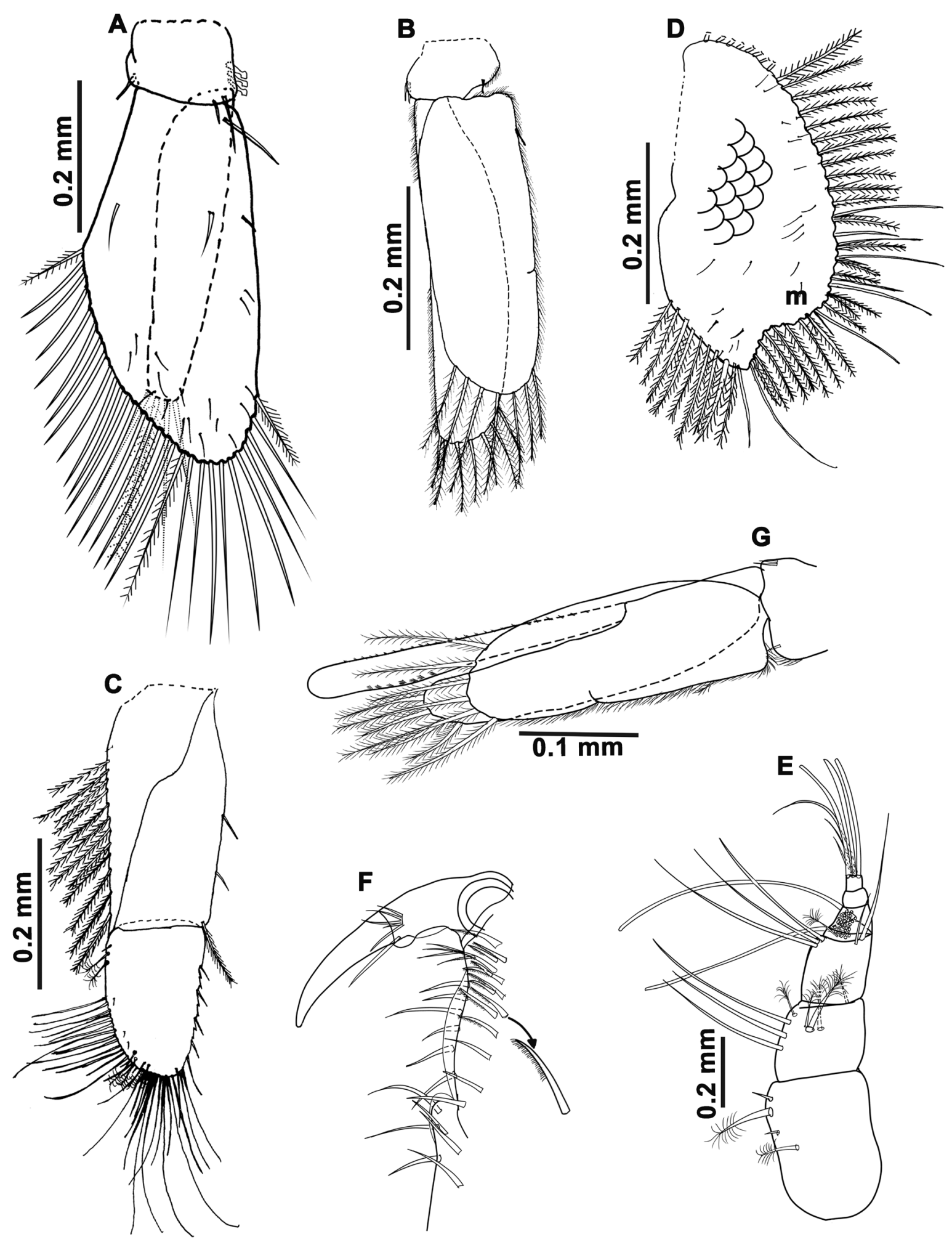

Fig. 19. Tinggianthura mexicana sp. nov. A-D. Holotype, $q, 3.7 \mathrm{~mm}$, Oaxaca, Huatulco, El Maguey Bay (UMAR-PERA 561). A. Pleopod 1. B. Pleopod 2. C. Uropodal endopod. D. Uropodal exopod. E-G. Paratype, ô, 3.9 mm (UMAR-PERA 562). E. Antennule. F. Pereopod 1. G. Pleopod 2. 
with a simple seta, distal margin surrounded by 29 plumose setae; endopod surrounded distally by four plumose setae.

Pleopod 2 (Fig. 19B). Exopod elongated oval, 0.8 times the length of endopod; endopod and exopod surrounded distally by seven plumose setae.

UROPODAL PROTOPOD (Fig. 19C). Rectangular, 1.6 times as long as endopod, external margin with a row of plumose setae, distoventral angle with a plumose seta.

Uropodal ENDOPOD (Fig. 19C). Oval, distally rounded, 1.5 times as long as wide, slightly longer than pleotelson; distal margin surrounded by simple and plumose sensory setae.

UROPODAL EXOPOD (Fig. 19D). Oval, distally excavated, 1.8 times as long as wide, margin surrounded by 52 long setae, eight simple and 44 plumose setae; dorsal surface covered by scales and some small setae.

Male (dimorphic characters; based on the paratype $\delta$, UMAR-PERA 562)

Antennule (Fig. 19E). Peduncle with three articles; article 1 almost twice as long as second, outer margin with plumose sensory setae; article 2 sub-square, outer margin with three long setae and sensory setae in distal margin; article 3 with three long setae in the dorsodistal angle and two on the ventral one; flagellum with four article, article 1 tiny; article 2 with a group of long aesthetascs; distal article with three aesthetascs and simple setae.

PeReopod 1 (Fig. 19F). Similar to the female; carpus triangular, rounded distally with a cuticular ridge and simple setae; palm slightly convex with a cuticular ridge and seven short marginal setae, mesial region with a row of smooth and pectinate setae.

Pleopod 2 (Fig. 19G). Exopod elongated oval, distal margin surrounded by six plumose setae; endopod longer than exopod, 0.6 times its width, distal margin with four plumose setae; male appendix cylindrical, rounded apex, distolateral margins with setulated scales.

\section{Distribution and habitat}

From Ixtapa, Guerrero to Huatulco, Oaxaca. In coral, coral rock, algae, tubes of sabellariids and sand; intertidal to subtidal $(6 \mathrm{~m})$.

\section{Remarks}

Tinggianthura alba Chew, Abdul-Rahim \& Haji Ross, 2014, described from Pulau Tinggi, Johor, Malaysia, is the only other species of this genus and differs from T. mexicana sp. nov. by having the following unique characteristics: body slightly pigmented; article three of mandibular palp with one pectinate seta; pleopod 1 with inner margin of protopod with two distal setae and exopod with inner proximal seta; and telson and uropodal exopod with scales on dorsal surface. Tinggianthura mexicana sp. nov. is similar to T. alba by the following characteristics: (1) the article 3 of the mandibular palp is almost a third of 1, (2) maxillipedal palp with two free segments, (3) palm of the pereopod 1 without a marginal projection, and (4) pleon as long as wide. The new species differs from T. alba by (1) distal setae of telson, (2) antennal flagellum, (3) lacinia mobilis, (4) molar process, and (5) palm of pereopod 1. While in T. alba the telson has three setae on the lateral margins and eight on the dorsal surface, the antennal flagellum has two articles, lacinia mobilis with five denticles, molar process is strongly projected, and the palm of pereopod 1 has many setae. In comparison, in the new species the telson has five lateral and 10 dorsal setae, antennal flagellum with three articles, lacinia mobilis with four teeth, molar process is truncated, and palm of the pereopod 1 with eight robust setae (Table 3). 


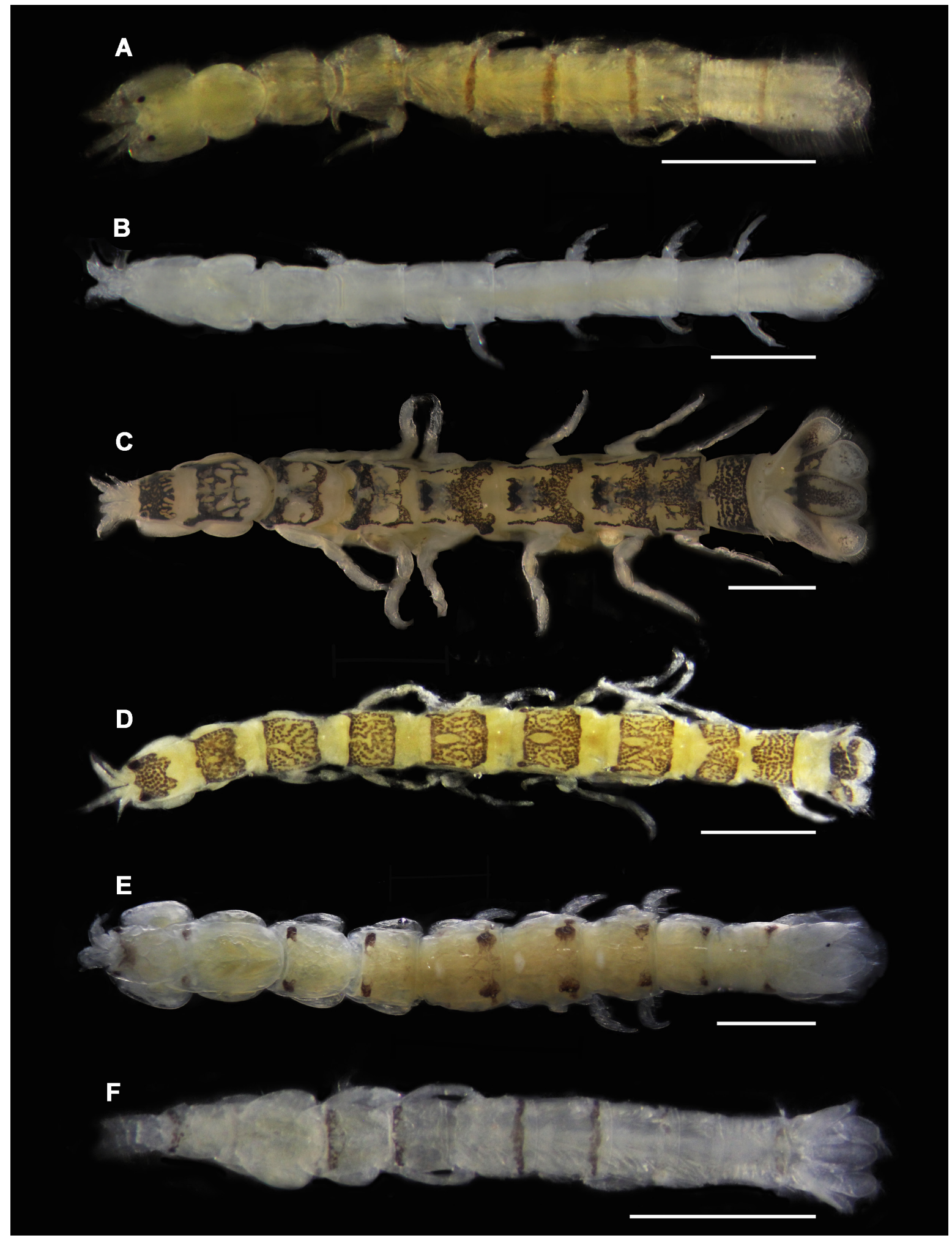

Fig. 20. A. Amakusanthura guerrerensis sp. nov., holotype, $q$ (UMAR-PERA 522). B. Cortezura caeca sp. nov., holotype, $q$ (UMAR-PERA 534). C. Mesanthura antenniformis sp. nov., paratype, $q$ (ovigerous) (UMAR-PERA 540). D. M. estacahuitensis sp. nov., holotype, + (UMAR-PERA 547). E. Skuphonura oaxaquensis sp. nov., holotype, $q$ (UMAR-PERA 548). F. Tinggianthura mexicana sp. nov., holotype, + (UMAR-PERA 561). Scale bars $=1 \mathrm{~mm}$. 
Table 3. Comparison between Tinggianthura alba Chew, Abdul-Rahim \& Haji Ross, 2014 of Malaysia and Tinggianthura mexicana sp. nov. from Oaxaca, Mexico.

\begin{tabular}{|c|c|c|}
\hline Character / species & $\begin{array}{l}\text { T. alba Chew, Abdul-Rahim \& } \\
\text { Haji Ross, } 2014\end{array}$ & Tinggianthura mexicana sp. nov. \\
\hline Locality & Pulau Tinggi, Johor, Malaysia & El Maguey Bay, Huatulco, Oaxaca \\
\hline Body length & $3.9 \mathrm{~mm}$ & $3.7 \mathrm{~mm}$ \\
\hline Body & Non pigmented & Slightly pigmented \\
\hline A1 flagellum & 3 articles & 3 articles \\
\hline A2 flagellum & 2 articles & 3 articles \\
\hline Article 3 of the mandibular palp & 2 smooth setae & 1 setulated seta \\
\hline Lacinia mobilis & 6 teeth & 4 teeth \\
\hline Maxillipedal palp & 2 articles & 2 articles \\
\hline Palm of P1 & Slightly convex & Convex \\
\hline Setae of protopod of P11 & None & 2 internal setae \\
\hline Setae of exopod of P11 & 29 distal & 1 long proximal and 29 distal \\
\hline Distal setae of endopod of P11 & 5 & 4 \\
\hline Scales on uropodal exopod & None & Present \\
\hline Scales on telson surface & None & Present \\
\hline Setae on subdistal region of telson & 3 marginal and 8 dorsal & 5 marginal and 10 dorsal setae \\
\hline Apical region of telson & $\begin{array}{l}\text { Slightly concave, } \\
3 \text { pairs of setae }\end{array}$ & $\begin{array}{l}\text { Slightly concave, } \\
3 \text { pairs of setae }\end{array}$ \\
\hline
\end{tabular}

\section{Discussion}

Although the Anthuridae are the largest and most widespread anthuridean family (Poore 2001), the taxonomic knowledge of the group is very limited in some regions of the world (e.g., eastern Pacific). Also, many genera are very widespread, and probably old, such as Cortezura, Skuphonura and Tinggianthura, which are represented by few species having been recorded only once and with restricted distribution, so it could be thought that these species probably present a high endemism as mentioned Kensley \& Schotte (2000).

Among the 26 genera of Anthuridae known in the world, five have been recorded in the tropical eastern Pacific, Cortezura, Cyathura Norman \& Stebbing, 1886, Haliophasma Haswell, 1881, Mesanthura and Skuphonura (Espinosa-Pérez \& Hendrickx 2001). With the present study, the number of genera increases to seven, recording for the first time Amakusanthura and Tinggianthura and the number of species increases from nine to 15. Also, Tinggianthura mexicana sp. nov. is the second species described in the genus. Likewise, Skuphonura oaxaquensis sp. nov. is the second species of the genus described from the tropical eastern Pacific, extending the distribution range of the genus from the coast of Ecuador to Oaxaca, Mexico. 
This study is the first work about anthurideans in the north eastern Pacific of Mexico, the discovery of these six new species is indicative of the marine biodiversity that still needs to be discovered from this region and, in general, from the Mexican Pacific (García-Madrigal et al. 2012; Bastida-Zavala et al. 2013; Jarquín-Gonzalez \& García-Madrigal 2013). Therefore, an exhaustive sampling at other localities, other habitats, or even sampling in deeper waters from the Mexican Pacific would reveal more undescribed species of these anthuridean isopods.

\section{Acknowledgments}

This work was supported partially by the projects "Poliquetos (Annelida) y eumalacostracos del golfo de Tehuantepec: taxonomía, colección de referencia, capacitación, claves de identificación, base de datos y página web" (FOSEMARNAT-2004-01-92) and "Evaluación del potencial de las técnicas de secuenciación masiva, ADN ambiental y código de barras genético para la descripción de la biodiversidad bentónica de los ecosistemas marinos y costeros de Oaxaca" (CONACyT 20151418). Many thanks to J. Rolando Bastida-Zavala (UMAR) by the revision of previous versions of this manuscript, and two anonymous reviewers for their valuable comments on the manuscript.

\section{References}

Bastida-Zavala J.R., García-Madrigal M.S., Rosas-Alquicira E.F., López-Pérez R.A., BenítezVillalobos F., Meraz-Hernando J.F., Torres-Huerta A.M., Montoya-Márquez A. \& Barrientos-Luján N.A. 2013. Marine and coastal biodiversity of Oaxaca, México. Chek List 9 (2): 329-390. https://doi.org/10.15560/9.2.329

Boyko C.B., Bruce N.L., Hadfield K.A., Merrin K.L., Ota Y., Poore G.C.B., Taiti S., Schotte M. \& Wilson G.D.F. (eds). 2008. World Marine, Freshwater and Terrestrial Isopod Crustaceans database. Anthuridae Leach, 1814. Available from

http://www.marinespecies.org/isopoda/aphia.php?p=taxdetails\&id=118244 [accessed 25 Jun. 2021].

Brusca R.C. 1980. A Handbook to the Common Intertidal Invertebrates of the Gulf of California. $2^{\text {nd }}$ Ed. University of Arizona Press, Tucson, Arizona.

Campos E. \& Villarreal G. 2008. Isópodos litorales y de aguas someras de la bahía de Todos los Santos, Baja California, México. Revista Mexicana de Biodiversidad 79: 347-354. Available from http://www.scielo.org.mx/pdf/rmbiodiv/v79n2/v79n2a7.pdf [accessed 1 Jul. 2021].

Chew M., Abdul-Rahim A. \& Haji Ross O.b. 2014. Tinggianthura alba: a new genus and species of Anthuridae (Isopoda, Cymothoida, Anthuroidea) from Pulau Tinggi, Johor, Malaysia with an updated key to the genera of Anthuridae. PLoS ONE 9 (6): e99072. https://doi.org/10.1371/journal.pone.0099072

Espinosa-Pérez M.C. \& Hendrickx M.E. 2001. Checklist of isopoda (Crustacea: Peracarida: Isopoda) from the Eastern Tropical Pacific. Belgian Journal of Zoology 131 (1): 43-55.

García-Madrigal M.S, Jarquín-González J. \& Morales-Domínguez E. 2012. Panorama del estado del conocimiento de los crustáceos del Pacífico sur de México. In: Sánchez A.J, Chiappa-Carrara X. \& BritoPérez R. (eds) Recursos Acuáticos, Costeros del Sureste Vol. 1: 396-414. Red para el Conocimiento de los Recursos Costeros de México, Yucatán, México.

Garm A. \& Watling L. 2013. The crustacean integument: setae, setules, and other ornamentation. In: Watling L. \& Thiel M. (eds) Functional Morphology and Diversity: 167-198. Oxford University Press, New York. https://doi.org/10.1093/acprof:osobl/9780195398038.001.0001

Jarquín-González J. \& García-Madrigal M.S. 2013. Annotated checklist and keys for cumaceans (Crustacea: Peracarida) from the Tropical Eastern Pacific, with six new species from the Southern Mexican Pacific. Zootaxa 3721 (3): 201-257. https://doi.org/10.11646/zootaxa.3721.3.1 
Kensley B. \& Schotte M. 2000. New species and records of anthuridean crustaceans from the Indian Ocean. Journal of Natural History 34: 2057-2121. https://doi.org/10.1080/002229300750022358

Menzies R.J. 1962. The marine isopod fauna of Bahía de San Quintín, Baja California, Mexico. Pacific Naturalist 3 (2): 337-348.

Negoescu I. 1994. Isopoda Anthuridea (Crustacea: Peracarida) from New Caledonia and Loyalty islands (south-western Pacific Ocean). Travaux du Muséum national d'Histoire naturelle "Grigore Antipa" 34: $147-225$.

Poore G.C.B. 2001. Families and genera of Isopoda Anthuridea. In: Kensley B. \& Brusca R.C. (eds) Isopod systematics and evolution. Balkema, Rotterdam. Crustacean Issues 13: 63-173.

Poore G.C.B. \& Bruce N.L. 2012. Global diversity of marine isopods (except Asellota and crustacean symbionts). PLoS ONE 7 (8): e43529. https://doi.org/10.1371/journal.pone.0043529

Manuscript received: 2 February 2021

Manuscript accepted: 1 May 2021

Published on: 21 July 2021

Topic editor: Rudy Jocqué

Desk editor: Pepe Fernández

Printed versions of all papers are also deposited in the libraries of the institutes that are members of the EJT consortium: Muséum national d'histoire naturelle, Paris, France; Meise Botanic Garden, Belgium; Royal Museum for Central Africa, Tervuren, Belgium; Royal Belgian Institute of Natural Sciences, Brussels, Belgium; Natural History Museum of Denmark, Copenhagen, Denmark; Naturalis Biodiversity Center, Leiden, the Netherlands; Museo Nacional de Ciencias Naturales-CSIC, Madrid, Spain; Real Jardín Botánico de Madrid CSIC, Spain; Zoological Research Museum Alexander Koenig, Bonn, Germany; National Museum, Prague, Czech Republic. 